\title{
WHEN DOES FAULTING-INDUCED SUBSIDENCE DRIVE DISTRIBUTARY NETWORK REORGANIZATION?
}

\author{
SEPTEMBER 29, 2021 \\ Non-peer reviewed manuscript submitted \\ for consideration in Geophysical Research Letters \\ Andrew J. Moodie $^{1^{*}}$ and Paola Passalacqua ${ }^{1}$
}

${ }^{1}$ Department of Civil, Architectural and Environmental Engineering, University of Texas at Austin, Austin, Texas, 78712

\begin{abstract}
Deltas exhibit spatially and temporally variable subsidence, including vertical displacement due to movement along fault planes. Faulting-induced subsidence perturbs delta-surface gradients, potentially causing distributary networks to shift sediment dispersal within the landscape. Sediment dispersal restricted to part of the landscape could hinder billion-dollar investments aiming to restore delta land, making faulting-induced subsidence a significant, yet unconstrained hazard to these projects. In this study, we modeled a range of displacement events in disparate deltaic environments, and observe that a channelized connection with the displaced area determines whether a distributary network reorganizes. When this connection exists, the magnitude of distributary network reorganization is predicted by a ratio relating dimensions of faulting-induced subsidence and channel geometry. We use this ratio to extend results to real-world deltas and assess hazards to deltaic-land building projects.
\end{abstract}

Keywords deltas $\cdot$ sediment diversions $\cdot$ land building $\cdot$ subsidence

\section{KEY POINTS}

- Faulting-induced subsidence reorganizes distributary networks, ephemerally restricting sediment dispersal and slowing land building

- Reorganization timing and style depend on self-organized avulsion style, and scale with a dimensionless displacement magnitude

- Faulting-induced subsidence presents an under-constrained hazard to land-building sediment diversions

\section{Plain Language Summary}

Coastal deltaic landscapes globally are losing area due to rising sea level and land subsidence. Billions of dollars in river diversions are planned on several deltas globally, intended to offset land loss by directing sediment necessary to sustain coastal land to areas experiencing land loss. Success of these projects depends on widespread sediment dispersal, distributed via extensive channel networks emerging from diversion sites. But, the possibility for rapid faulting-induced subsidence to restrict channel networks and limit land building has not been adequately considered in diversion planning. Here, we present numerical simulations that show how faulting-induced subsidence impacts sediment dispersal, and how this informs hazards present to planned Mississippi River delta sediment diversions.

\section{INTRODUCTION}

Deltas provide numerous societal and environmental benefits (Chaplin-Kramer et al., 2019; Hoitink et al., 2020), as well as engender cultural and personal identity (e.g., Zeisler-Vralsted, 2019). Anthropogenic landscape modifications, including levees and channel dredging, limit sediment dispersal necessary to raise deltaic land with respect to water level, thereby promoting widespread land loss by inexorable subsidence (e.g., Paola et al., 2011; Hoitink et al., 2020). Efforts to restore deltaic land (e.g., Peyronnin et al., 2013) rely on a robust understanding of natural sediment dispersal processes (Kolker, Miner, \& Weathers, 2012; Giosan, Constantinescu, Filip, \& Deng, 2013; Temmerman \& Kirwan, 2015; Hoitink et al., 2020), as well as how dispersal is affected by disturbances, such as spatially and temporally variable subsidence (Kolb \& Van Lopik, 1958; Shirzaei et al., 2020). Temporally-discrete faulting-induced subsidence manifests at space and time scales similar to delta restoration efforts $\left(10^{3} \mathrm{~m}\right.$ and $10^{2}$ yr) (Gagliano, Kemp III, Wicker, Wiltenmuth, \& Sabate, 2003; Kim, Mohrig, Twilley, Paola, \& Parker, 2009), but it is not known whether perturbation by subsidence causes distributary networks to reorganize. Reorganization could limit sediment dispersal extent (Liang, Kim, \& Passalacqua, 2016) or cause sediment to bypass areas targeted for land restoration (Kim et al., 2009). We need to understand the impact of faulting-induced subsidence on distributary network evolution to make robust predictions for deltaic land building.

Deltaic land builds where sediment deposition exceeds accommodation space, and is accordingly dependent on processes that disperse sediment and lower the land surface (Paola et al., 2011); importantly though, dispersal is affected by lowering, and lowering is affected by dispersal. For example, continuous tectonic subsidence "steers" channels toward areas of greater accommodation due to lateral (i.e., cross basin) topographic gradients (Bridge \& Leeder, 1979; Heller \& Paola, 1996; Kim, Sheets, \& Paola, 2010; Reitz et al., 2015). Persistent longitudinal topographic gradients (i.e., down basin) limit channel mobility by "locking" sediment conduits with downstream sinks (Liang, Kim, \& Passalacqua, 2016). In an opposite feedback, tectonic subsidence in deltaic environments commonly includes movement along fault planes, caused by gravitational instability from accumulating sediment (e.g., salt tectonics, slumps, growth 
faults; Gagliano, Kemp III, Wicker, \& Wiltenmuth, 2003). In turn, accumulated growth fault displacement may affect channel orientation and location (Armstrong, Mohrig, Hess, George, \& Straub, 2014; Gasparini, Fischer, Adams, Dawers, \& Janoff, 2016).

These aforementioned patterns constitute time-integrated system behavior and do not predict channel evolution and sediment dispersal at timescales pertinent to coastal restoration $\left(10^{2} \mathrm{yr}\right)$. Indeed, channels ordinarily locate irrespective of time-integrated subsidence patterns (Hickson, Sheets, Paola, \& Kelberer, 2005; Kim et al., 2010; Straub \& Esposito, 2013; Gasparini et al., 2016; Liang, Kim, \& Passalacqua, 2016). Significant vertical fault displacement $10^{0}-10^{1} \mathrm{~m}$ over less than one year has been observed (Gagliano, Kemp III, Wicker, \& Wiltenmuth, 2003; Shchetnikov, Radziminovich, Vologina, \& Ufimtsev, 2012), but fault activity varies in space and time (Mouslopoulou, Walsh, \& Nicol, 2009; Fossen, 2020). As a result, land building studies have not accounted for faulting-induced subsidence influence on distributary network processes (e.g., Army Corps of Engineers, 2021).

Predicting displacement timing across decades is unlikely (e.g., Geller, 1997), and so site-specific modeling of channel network evolution due to displacement has limited application in coastal restoration. Instead, a framework describing how sediment dispersal and land building are affected if faulting-induced subsidence occurs, would be more helpful. This framework should be interpretable for any delta and across scales of faulting.

\section{SCALES OF FAULTING-INDUCED SUBSIDENCE AND CHANNEL NETWORK REORGANIZATION}

Two motivating examples of faulting-induced subsidence on deltas illustrate scales to be considered. At one end, earthquakerelated faulting along $\sim 10^{1} \mathrm{~km}$ faults infrequently $(\sim 500 \mathrm{yr}$ period) displaces a moderate portion of a delta area by several meters vertically (Shchetnikov et al., 2012). At the other end, regional $\left(10^{2} \mathrm{~km}\right.$ length) and local $\left(10^{0}-10^{1} \mathrm{~km}\right)$ listric normal faults (growth faults) are ubiquitous on low-lying deltas, and are sporadically but frequently active over centuries, averaging to $<1-70 \mathrm{~cm} / \mathrm{yr}$ (Gagliano, Kemp III, Wicker, Wiltenmuth, \& Sabate, 2003). Deltaic faulting-induced subsidence occurs on a spectrum, with bounds on space and time dimensions represented by these scenarios.

\subsection{Example: large disturbance and wholesale reorganization}

The Selenga River delta historical shoreline position documents distributary network reorganization following faultinginduced subsidence. Situated along the margin of rift-basin bound Lake Baikal (Russia), the Selenga River delta is tectonically active (Figure 1a; Déverchére et al., 2001; Krivonogov \& Safonova, 2017). An earthquake in 1862 induced up to $9 \mathrm{~m}$ of vertical displacement along the eastern delta edge (Orlov, 1872), lowering $>230 \mathrm{~km}^{2}$ of land below the water surface and creating Proval Bay (Figure 1a; Vologina et al., 2010; Shchetnikov et al., 2012). As a result, the shortest path from delta apex to lake level was available via Proval Bay (i.e., eastern deltaic lobe). A bathymetric survey of Proval Bay following the earthquake indicated 1-5 m water depth centrally, and shallower 0.7-1.5 m depth proximal to the delta (Orlov, 1872). In the $\sim 160$ years since, the shoreline along the eastern lobe (i.e., at Proval Bay) has prograded faster than elsewhere along the delta front, and has reached a condition that restores delta planform radial symmetry (Figure 1a; Dong, 2020).

Measurements of Proval Bay water depth and delta subaerial change suggest $6.8 \pm 2.1 \times 10^{7} \mathrm{~m}^{3}$ of accommodation has been filled in $\sim 160$ years (Supporting Information). Scaling this volume to the estimated annual bed material input to the delta $\left(2.4 \pm 0.2 \times 10^{5} \mathrm{~m}^{3}\right.$; Dong, 2020) and applying a constant sediment depositional porosity and compaction (Supporting Information; (Törnqvist et al., 2008)) with present deltaic lobe partitioning (three lobes, $23 \%$ to eastern lobe; Il' icheva, Pavlov, \& Korytny, 2014; Dong et al., 2020; Dong, 2020) or equal lobe partitioning (33\% to eastern lobe) accounts for only 16 to $59 \%$ of the observed deposited sediment volume. To match the observed sediment volume, 62 to $>95 \%$ of sediment input to the delta over $\sim 160$ years must have gone to the eastern lobe (Supporting Information), implying wholesale distributary network reorganization following displacement, and subsequently balanced sediment partitioning among deltaic lobes. The 1862 Selenga River delta displacement event exemplifies one endmember scale of faulting, wherein a large disturbance caused a dramatic response in the delta network.

\subsection{Example: unsteady activity with unknown effect}

The Mississippi River delta is a testbed for sediment diversions, which are designed to deliver sediment volume in excess of accommodation space and build land. Diversions are sized from sediment budgets that use estimated and historical subsidence patterns (e.g., Kim et al., 2009; Sanks, Shaw, \& Naithani, 2020), so that either unexpected subsidence or deficient sediment dispersal could stymie land building. Within the delta, regional $\left(10^{2} \mathrm{~km}\right.$ length) and local $\left(10^{0}-10^{1} \mathrm{~km}\right)$ growth faults (Figure 1b; Gagliano, Kemp III, Wicker, Wiltenmuth, \& Sabate, 2003) have measured displacement rates $16.9 \mathrm{~mm} / \mathrm{yr}$ over the late 20th century (Dokka, 2006, 2011), and anecdotally up to $>1.4 \mathrm{~m}$ in two years (Gagliano, Kemp III, Wicker, Wiltenmuth, \& Sabate, 2003; Gagliano, Kemp III, Wicker, \& Wiltenmuth, 2003). Rates are difficult to compare across timescales (e.g., Jerolmack \& Sadler, 2007; Mouslopoulou et al., 2009), thus confounding agreement on the timing of faulting-induced subsidence (e.g., Edrington, 2005; Meckel, ten Brink, \& Williams, 2006; Morton \& Bernier, 2010; Nienhuis, Törnqvist, Jankowski, Fernandes, \& Keogh, 2017). Nevertheless, faulting-induced subsidence at regional and local scales presents a potentially significant hazard to diversion success.

\section{Simulating FAULTING-INDUCED SUBSIDENCE ACROSS A RANGE OF SCALES}

Inspired by the compelling example of faulting-induced distributary reorganization on the Selenga River delta and a need to evaluate hazards to Mississippi River delta sediment diversions, we ask: what scale of displacement (vertical slip and areal extent) drives distributary network reorganization, and are equilibrium sediment distribution processes eventually restored? We implemented numerical experiments to address these questions: we apply a perturbation with varied vertical displacement length 

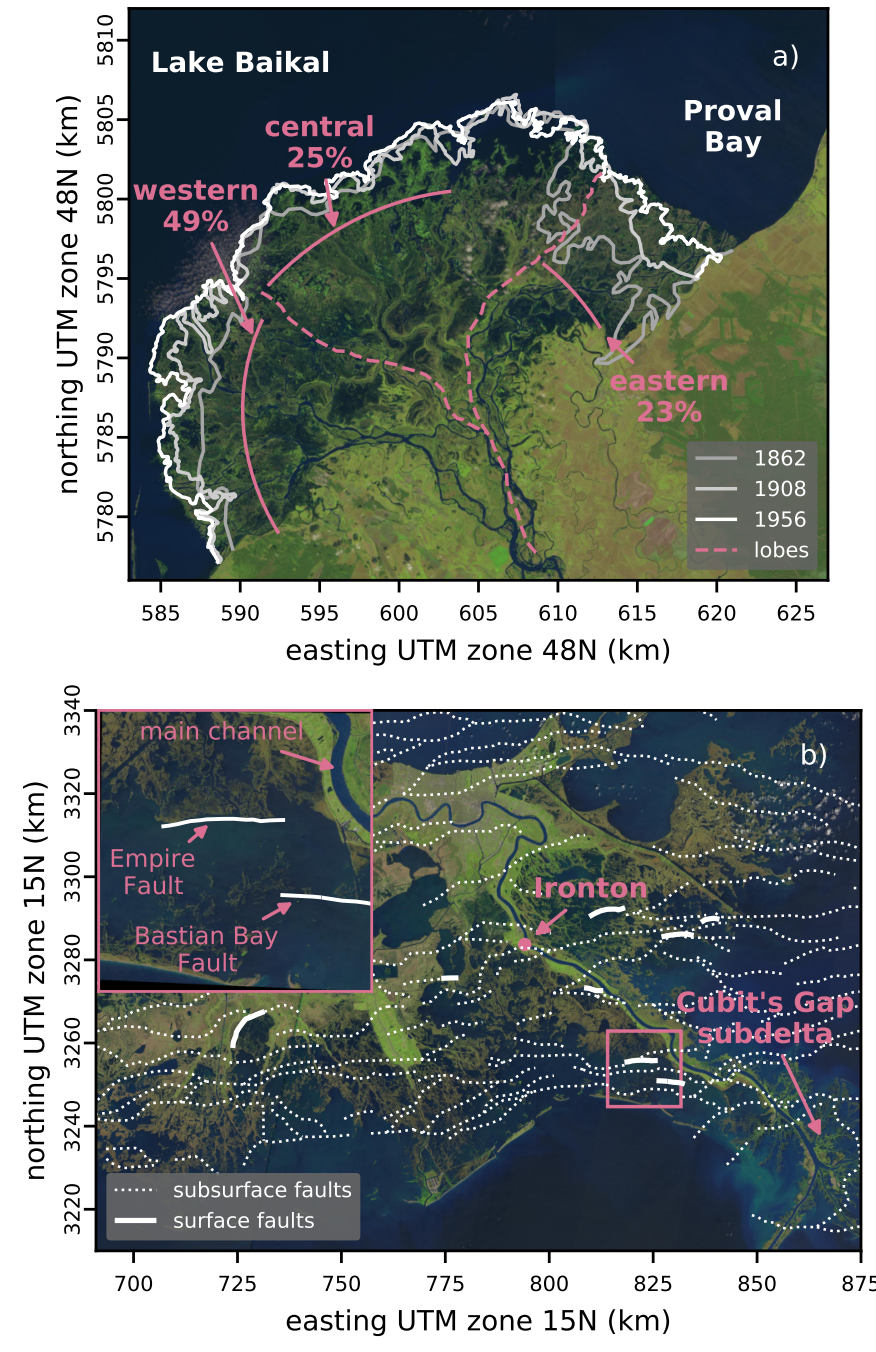

Figure 1: Examples of faulting-induced subsidence on deltas. b) Mississippi River delta, imaged from Sentinel 2 in March 2021. Faults with down-to-south motion locate across the delta topset (Gagliano, Kemp III, Wicker, \& Wiltenmuth, 2003; Armstrong et al., 2014; Culpepper et al., 2019), and a subset of these faults reach the surface (inset). Water and sediment exiting main-channel diversions (e.g., at Ironton) may be affected by faulting-induced displacement.
$\left(H_{\sigma}\right)$ and fault-block area $\left(A_{\sigma}\right)$ to a consistent initial state, and observe subsequent deltaic system evolution. The perturbation was modeled as instantaneous vertical land movement (i.e., displacement without hanging-wall rotation or translation), with channel evolution and geometry before and following displacement emerging based on model boundary conditions (Supporting Information). Simulations used the DeltaRCM numerical delta model (Liang, Voller, \& Paola, 2015a), implemented in Python as pyDeltaRCM (Moodie, Hariharan, Barefoot, \& Passalacqua, 2021). DeltaRCM has been robustly validated (Liang, Geleynse, Edmonds, \& Passalacqua, 2015b; Liang, Van Dyk, \& Passalacqua, 2016) and used to examine delta morphology and evolution under various external forcings, including sea-level rise (Liang, Van Dyk, \& Passalacqua, 2016), and presence of vegetation (Lauzon \& Murray, 2018), and ice and permafrost (Lauzon, Piliouras, \& Rowland, 2019; Piliouras, Lauzon, \& Rowland, 2021). The model does not consider the effects of sediment compaction (e.g., Törnqvist et al., 2008), organic matter accretion (e.g., Sanks et al., 2020), or waves and tides on delta land building (e.g., Nienhuis et al., 2020), but can be expected to capture first-order distributary network behavior, since the primary land-building material is riverine sediment in the study areas (Kolker et al., 2012). We included replicate simulations for each displacement size (after Liang, Kim, \& Passalacqua, 2016) and simulations without displacement, to assess autogenic variability and quantify uncertainty in distributary response.

Experiment Set 1 begins with a deltaic system qualitatively similar to the Selenga River delta (Figure $1 \mathrm{a}$ and 2a; parameters listed in Supporting Information). Namely, the model delta maintains several active distributary channels (6-8; Il'icheva et al., 2014; Dong et al., 2020) and an approximately radially symmetric subaerial planform (Reitz \& Jerolmack, 2012; Dong, 2020). Set 1 varied $H_{\sigma}=\{0.01,0.02,0.05,0.1,0.2,0.5,1,2,5\}$ meters while holding fault block width $\left(B_{\sigma}\right)$ and length $\left(L_{\sigma}\right)$ fixed at 6.5 and $12 \mathrm{~km}$, respectively, and locating the fault (i.e., block edge nearest the delta inlet) randomly along an arc $6 \mathrm{~km}$ from the delta inlet (Figure 2c-f; seven replicates, total 70 simulations). Set 1 displacement lengths and block width range Selenga River delta observations (Shchetnikov et al., 2012; Dong, 2020).

The deltaic system beginning Experiment Set 2 is qualitatively similar to the Mississippi River delta (Figure 1b and 2b; parameters listed in Supporting Information). The Set 2 delta system maintains 1-2 active distributary channels, and an asymmetric planform with high topography isolated along relict alluvial ridges and surrounded by shallow embayments. Set 2 varied displacement length $H_{\sigma}=\{0.1,1,5\}$ meters and fault block area, by modulating block width $B_{\sigma}=\{3.6,12,24\} \mathrm{km}$ and holding block length $L_{\sigma}=9.6 \mathrm{~km}$. The fault location was constrained to $30-56 \mathrm{~km}$ from the delta inlet and placed randomly (Figure $2 \mathrm{~g}-\mathrm{j}$; eleven replicates, total 110 simulations).

\section{DELTA RESPONSE TO FAULTING-INDUCED SUBSIDENCE}

Displacement changes delta planform by causing land flooding, and influences the distributary network by altering deltasurface gradients (i.e,. geometric topset scaling; Swenson, Voller, Paola, Parker, \& Marr, 2000, Figure 2c-i). Subsequent planform change indirectly records distributary network 

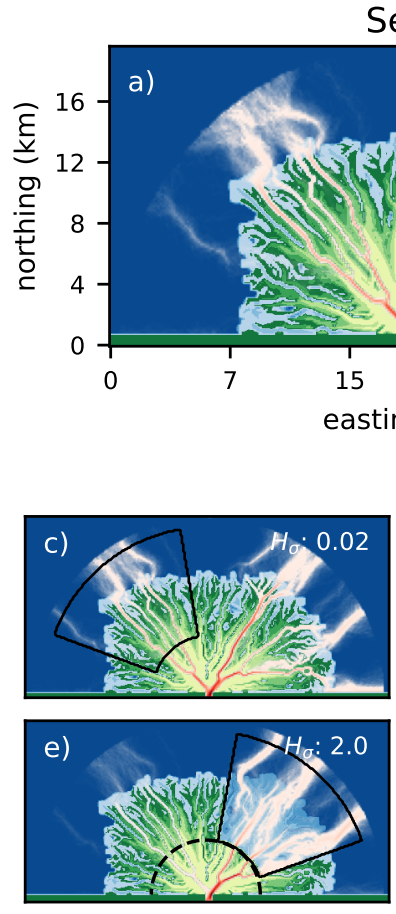

Set 1

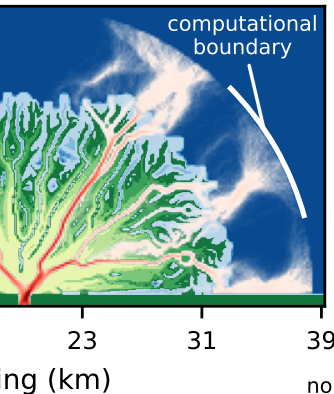

normalized discharge $(\%)$

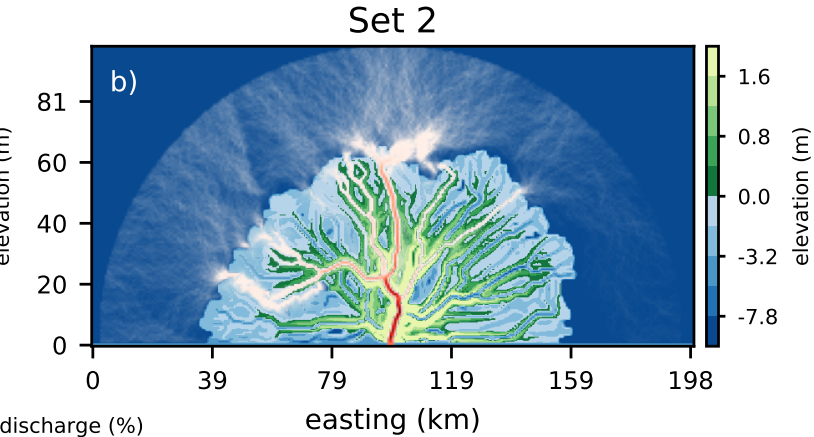

easting $(\mathrm{km})$
5
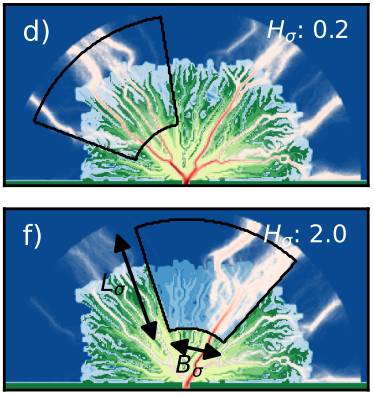

50
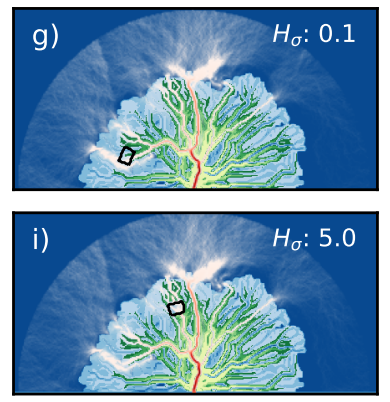
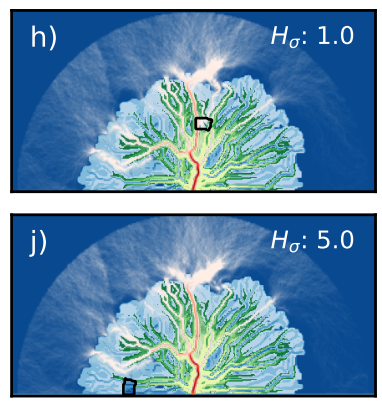

Figure 2: Planform view of numerical experiment setup. Experiment a) Set 1 delta and b) Set 2 delta bed elevation immediately before slip event. Unit-cell water discharge normalized to the inlet flow is overlayed as white-to-red colors (with transparency $<5 \%$ ). Selected simulations from $\mathrm{c}-\mathrm{f}$ ) experiment Set 1 and $\mathrm{g}-\mathrm{j}$ ) Set 2, depicted immediately following displacement event, wherein black contour demarcates fault block extent. Bottom panels (e \& f, i \& j) demonstrate replicate simulations, where displacement length and block area was unchanged but location varied.

response, whereas network response is directly recorded in spatiotemporal sediment flux partitioning across the landscape. Flux partitioning measurements are rare from deltas (Dong et al., 2020), but accessible in simulations. Therefore, we analyzed model simulations with indirect and direct metrics (Supporting Information), ensuring our analyses are comparable to historical records and can be generalized to predict reorganization in real-world deltas.

\subsection{Planform morphology}

Keeping in mind the objective to build new land by sediment diversion, we quantified subaerial delta land area $\left(A_{L}\right)$ as:

$$
A_{L}=\sum_{i=1}^{L} \sum_{j=1}^{W} A_{i j}
$$

where $i$ and $j$ are model cell indices, $L$ and $W$ are the number of cells in each dimension of the model domain, and

$$
A_{i j}=\left\{\begin{array}{ll}
d x^{2} & : \eta_{i j}>H_{W L} \\
0 & : \eta_{i j} \leq H_{W L}
\end{array},\right.
$$

where $d x$ is the model grid cell size, $\eta$ is the bed elevation, and $H_{W L}$ is the basin water level. Subaerial delta area abruptly decreases proportionate to displacement length in Experiment Set 1 (Figure 3a), but area does not change predictably for Set 2 (i.e., within autogenic variability; Figure 4a). Deltaic land area unsteadily increases in Set 1 and Set 2 simulations, though Set 2 increase is non-monotonic and more variable (Figures $3 \mathrm{a}$ and $4 a)$.
Approximately one-third of the Selenga River delta width was lowered by the 1862 earthquake, creating a radially asymmetric delta planform (Shchetnikov et al., 2012; Dong, 2020). We quantified this delta asymmetry $\left(R_{r}\right)$ in simulations as a ratio:

$$
R_{r}=\frac{r_{\sigma}}{r},
$$

where $r_{\sigma}$ and $r$ are the mean distance from delta apex to points along the shoreline within the subsided block and across the entire delta, respectively (shoreline identified by the Opening Angle method; Shaw, Wolinsky, Paola, \& Voller, 2008). Set 1 deltas become asymmetric immediately following displacement $\left(R_{r}<1\right.$ and outside autogenic variability) for displacement greater than $\sim 0.2 \mathrm{~m}$ (Figure $3 \mathrm{~b}$ ). Then, $R_{r}$ increases, at a different rate for each displacement length, until the shoreline position reaches a dynamic equilibrium (i.e., delta symmetry, $R_{r} \approx 1$; Figure $3 b$ ). Fault block area and shoreline do not necessarily overlap in Experiment Set 2, rendering delta asymmetry uninformative for this set.

\subsection{Distributary network organization}

Simulations yield sediment transport data at spatiotemporal resolution unparalleled in real-world systems (Hoitink et al., 2020) and invaluable for understanding delta evolution following faulting-induced subsidence. We quantified shifting distributary network organization via sediment flux asymmetry $\left(R_{Q_{s}}\right.$, i.e., sediment partitioning):

$$
R_{Q_{s}}=\frac{Q_{s, \sigma}}{Q_{s}},
$$



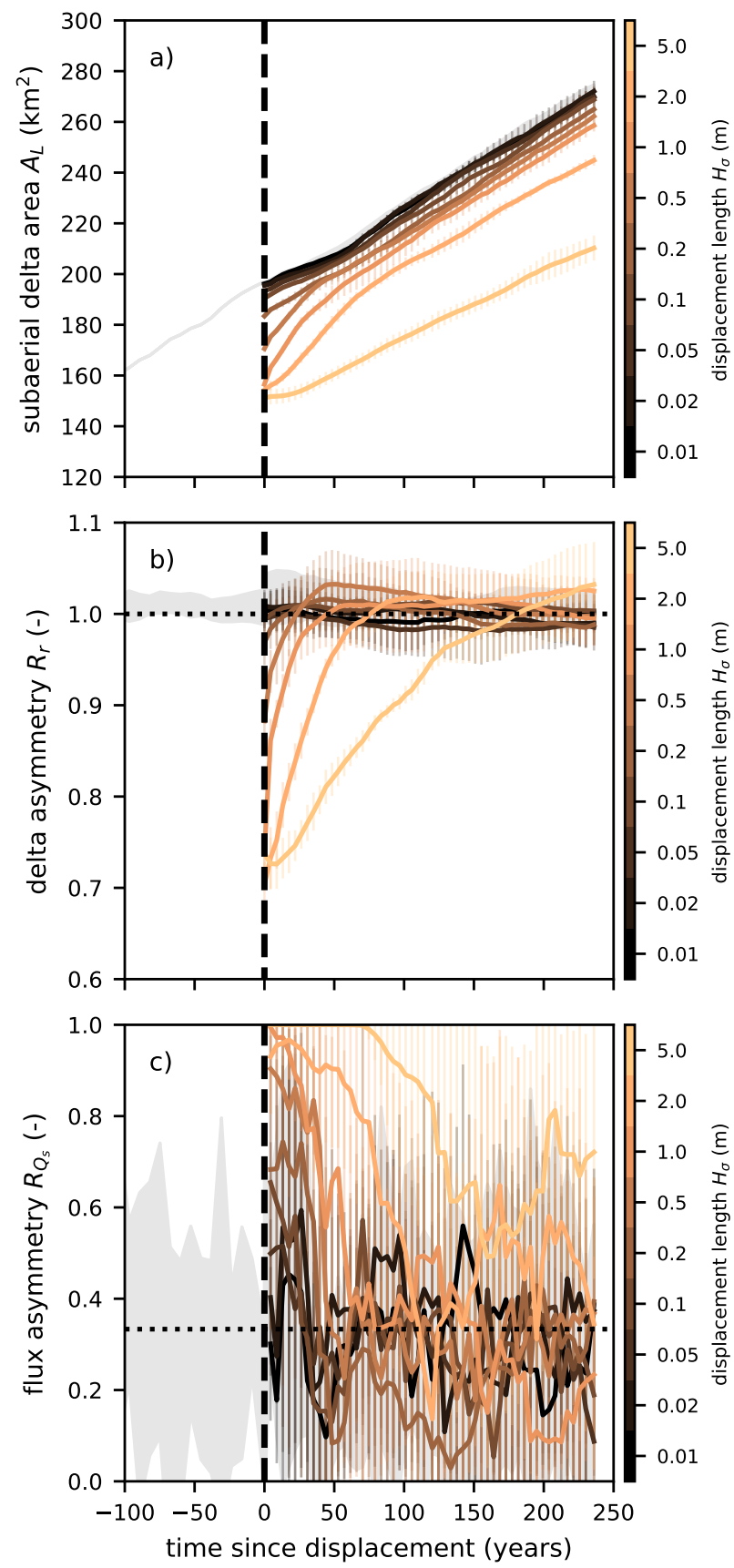

Figure 3: Experiment Set 1 results. a) Subaerial delta area $\left(A_{L} ;\right.$ Equation 1$)$. b) Delta asymmetry $\left(R_{r} ;\right.$ Equation 3$)$. Values less than unity describe asymmetry due to faulting-induced subsidence in simulations. c) Sediment flux asymmetry $\left(R_{Q_{s}}\right.$ Equation 4). Time-averaged sediment partitioning is balanced $\approx 0.33$, and shift towards unity indicates sediment partitioning due to network reorganization. In a-c), solid lines and error bars are mean and standard deviation for replicate simulations from each displacement length, gray shaded region is autogenic variability without faulting-induced subsidence, and black vertical dashed line marks displacement timing. where $Q_{s, \sigma}$ is sediment flux into the subsided block, and $Q_{s}$ is sediment flux across the delta, calculated through a circular cross-section positioned at the fault (Figure 2c-i). In Experiment Set 1 , sediment flux partitioning is approximately symmetric for displacement lengths $\leq 0.1 \mathrm{~m}\left(R_{Q_{S}} \approx 0.33\right.$, as the subsided block measures one-third of the delta width). For larger displacement lengths, sediment is consistently partitioned into the subsided block $\left(R_{Q_{s}} \rightarrow 1\right.$; Figure 3c), and duration of asymmetric flux scales with displacement length (Figure $3 \mathrm{c}$ ) and is coincident with delta asymmetry (Figure $3 b$ ). For Set 2 , flux asymmetry following the displacement event depends weakly on displacement length, but decorrelates a short time later (Figure 4b). Shifted flux in Set 1 and Set 2 demonstrates that disequilibrium in deltasurface gradients created by faulting-induced subsidence drives distributary network reorganization to restore equilibrium.

In many Set 2 simulations, fault location is disconnected from the channel network (Figure $2 \mathrm{~g}-\mathrm{j}$ ), which categorizes simulations as either "connected" or "not connected", based on whether the subsided block had $>5 \%$ of the inlet unit-cell discharge at the time of displacement (Figure 2). Connectedness dictates when sediment first enters the subsided block ( $T_{0}$, Figure $\left.4 \mathrm{c}\right)$, with blocks receiving sediment a median time of 9 and 381 years later for connected and not-connected locations, respectively $\left(p=7.0 \times 10^{-13}\right.$ for an unequal variances $t$-test). Volumetric sediment flux into the subsided block at time $T_{0}\left(Q_{s, 0}\right.$, Figure $4 \mathrm{~d})$ is indistinguishable between connected and not-connected Set 2 simulations $\left(p=2.3 \times 10^{-1}\right)$. All Set 1 simulations are connected ( $>5 \%$ inlet unit-cell discharge), causing networks to swiftly reorganize after displacement (i.e., $T_{0} \approx 0$ ), and correlating volumetric sediment flux to the subsided block (i.e., $Q_{s, 0}$ ) with displacement length (Figure 3c).

\subsection{Style and timing of distributary network reorganization}

Differences in reorganization predictability between Set 1 and 2 are due to distributary network configurations unique to each set, that arise from autogenic sediment dispersal characteristics. Set 1 simulations shift sediment dispersal over time via soft avulsion (Edmonds, Paola, Hoyal, \& Sheets, 2011), whereas sediment dispersal shifts in Set 2 simulations by deltaic lobe-switching avulsion (Supporting Information; Slingerland \& Smith, 2004). Soft avulsion leads to multiple active distributary outlets in a branching channel network (Dong et al., 2020), which ensures connectedness (and thus reorganization). In contrast, lobe-switching avulsion abandons channel courses and limits active sediment transport extent, such that connectedness (and thus reorganization) depends on fault location.

Avulsion behavior continues to control spatiotemporal sediment distribution after initial reorganization (or stasis). For example, sediment flux timing of not-connected simulations $\left(T_{0}\right)$ is distributed approximately uniformly in time (Figure $4 \mathrm{c}$ ), which is consistent with periodic avulsions (e.g., Mohrig, Heller, Paola, \& Lyons, 2000), and channel location is determined by pre-existing topography (e.g., Hajek \& Edmonds, 2014) rather than being steered towards the subsided region. Moreover, indistinguishable sediment flux $Q_{s, 0}$ (Figure $4 \mathrm{~d}$ ) indicates avulsed channels are self-formed (Slingerland \& Smith, 2004; Hajek \& Edmonds, 2014), because channels convey consistent sediment flux, regardless of displacement scale or timing. Gradual recovery of balanced sediment partitioning following abrupt 

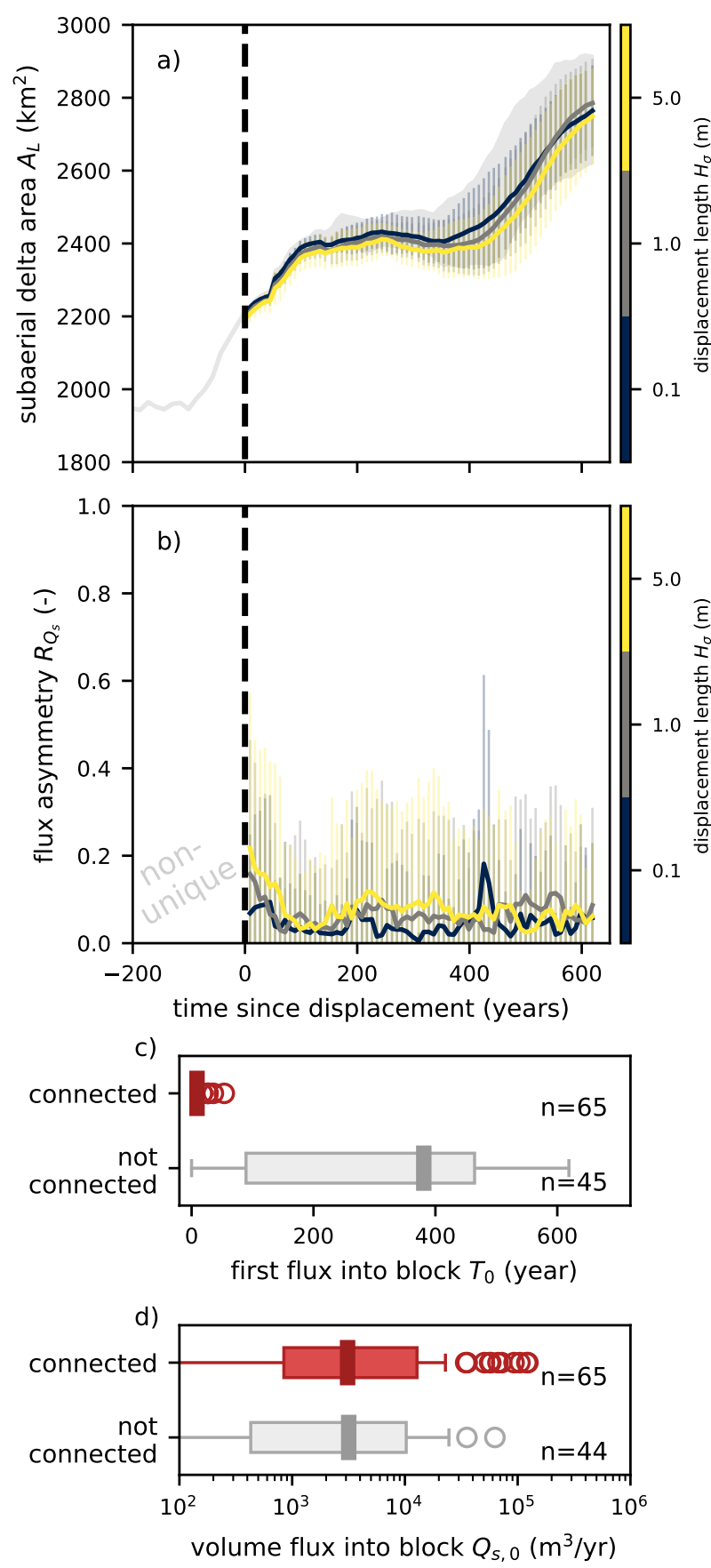

Figure 4: Experiment Set 2 results. a) Delta subaerial land area $\left(A_{L} ;\right.$ Equation 1$)$. b) Sediment flux asymmetry $\left(R_{Q_{s}}\right.$; Equation 4). In $\mathrm{a}-\mathrm{b})$, solid lines and error bars are mean and standard deviation for replicate simulations from each displacement length, gray shaded region is autogenic variability without faultinginduced subsidence, and black vertical dashed line marks displacement timing. For Set 2 simulations categorized by connectedness (see text): c) time since displacement when sediment first enters the subsided block $\left(T_{0}\right)$, and d) volumetric sediment flux into the block at that time $\left(Q_{s, 0}\right)$. Flux timing depends on connectedness, but volumetric flux is indistinguishable.

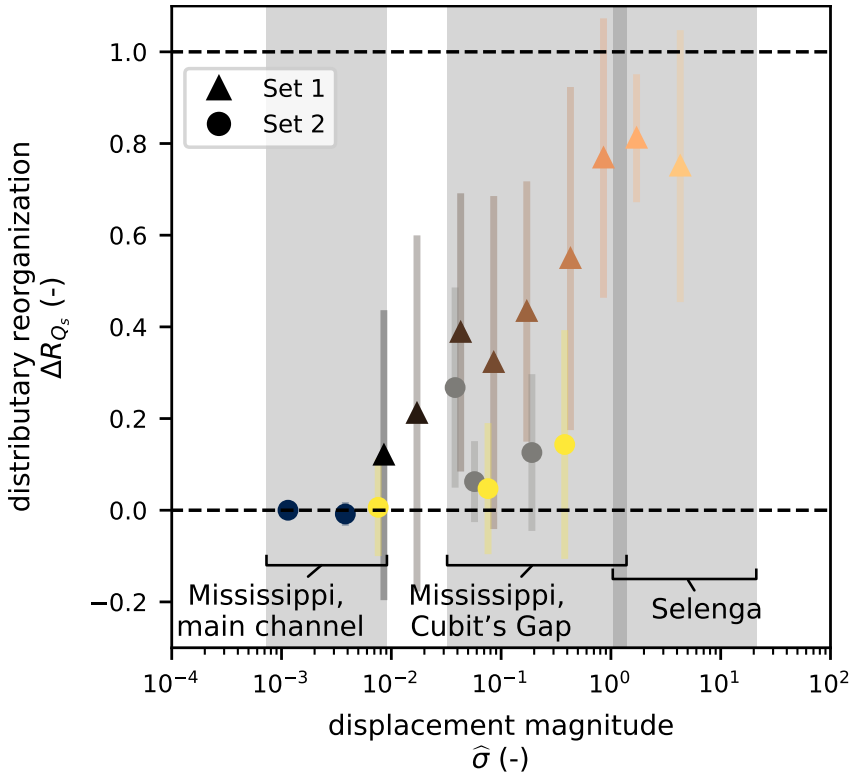

Figure 5: Distributary network reorganization $\left(\Delta R_{Q_{s}}\right)$ for displacement magnitudes (Equation 5) of Set 1 (triangles) and Set 2 (circles) simulations and field cases; multiple same-color symbols represent displacement length and fault width pairs in Set 2 simulations (i.e., increasing displacement magnitude for a given color is due to increasing fault width). Not-connected simulations from Set 2 were omitted, and symbols and error bars represent mean and standard deviation of replicate simulations, respectively. Grey bands in Figure 5 depict displacement magnitude range estimated for real-world distributary systems (Supporting Information). Faulting-induced subsidence scaling on the Mississippi River delta indicates likely distributary network reorganization within deltas built from sediment diversion efflux (e.g., at scale of Cubit's Gap).

reorganization in Experiment Set 1 (Figure 3c) is consistent with sediment dispersal via soft avulsion. Ephemeral sediment flux reorganization documented herein is in contrast to channel "locking" due to distal continuous subsidence (Liang, Kim, \& Passalacqua, 2016).

\section{PREDICTING THE IMPACTS OF FAULTING-INDUCED SUBSIDENCE}

Model behavior aligns with observations from real-world deltas that motivated this research. For example, multiple active distributary channels and soft avulsion are observed on the Selenga River delta (similar to Set 1; Dong et al., 2016; Dong, 2020). Additionally, lobe-switching avulsion commonly controls sediment distribution in single-threaded deltaic systems like the Mississippi River delta (similar to Set 2; Roberts, 1997; Jerolmack \& Mohrig, 2007). Ephemeral asymmetric shoreline progradation focused along the subsided block in Set 1 (Figure $3 c)$ is consistent with the Selenga River delta historical record (Figure 1a) and modern delta partitioning (Dong et al., 2020). Behavioral similarity between model and real-world across disparate deltaic systems is encouraging for efforts to extrapolate 
model results to inform land building and distributary networks in real-world deltaic environments.

\subsection{Impacts on land building}

Land building at the delta scale is not significantly impacted by faulting-induced subsidence in most simulations (Figures $3 \mathrm{a}$ and $4 \mathrm{a})$, though, land emergence may be delayed due to increased accommodation created by subsidence (Figure 3ab). Mississippi River delta sediment budgets indicate sufficient resources for land building (Kim et al., 2009; Nittrouer \& Viparelli, 2014; Sanks et al., 2020) and channels are mobile after filling accommodation (Figure $3 \mathrm{a}-\mathrm{b}$ ), ensuring that sediment does not bypass the delta topset indefinitely (Figures 3 and 4; Supporting Information). Together, simulation results suggest that sediment dispersal processes (i.e., avulsions) will maintain delta-scale landscape sustainability, despite affecting local areas (Passalacqua, Giosan, Goodbred, \& Overeem, 2021).

Faulting-induced subsidence and restricted sediment dispersal potentially stymie land building downstream of diversions (i.e., at a local scale; Figures $3 \mathrm{c}$ and $4 \mathrm{~b}$ ). Land-building models not accounting for reorganization (e.g., Army Corps of Engineers, 2021) potentially overestimate extent and location for land building. Though, reorganization is ephemeral and distributive sediment dispersal is restored without intervention (Figures $3 \mathrm{c}$ and $4 \mathrm{c}-\mathrm{d}$ ), so timing of land building may be impacted by faulting-induced subsidence, but land will eventually emerge.

\subsection{Impacts on distributary network organization}

Association between paleo-channels and faults mapped in the subsurface led Armstrong et al. (2014) to hypothesize that channel reorganization depends on the relative scale of fault displacement and channel size. Building on this idea, we determined a dimensionless scaling ratio relating displacement event and distributary network characteristics that we term the displacement magnitude $(\widehat{\sigma})$ :

$$
\widehat{\sigma}=F_{w} \frac{B_{\sigma} H_{\sigma}}{B_{c} H_{c}},
$$

where $F_{w}$ is fraction of delta width channelized (akin to nearest edge distance; Edmonds et al., 2011), $\boldsymbol{B}_{c}$ is channel width, and $H_{c}$ is channel depth, all measured at the fault distance from delta apex immediately before the simulated displacement (Supporting Information). Figure 5 shows the relationships between displacement magnitude $(\widehat{\sigma})$ and distributary network reorganization $\left(\Delta R_{Q_{s}}\right)$, which we quantified as the difference between sediment flux asymmetry before and after displacement (Figures $3 c$ and $4 b$ ); not-connected simulations from Set 2 were omitted.

Expected reorganization increases as displacement becomes larger relative to the distributary network (Figure 5). Equation 5 codifies variables needed to characterize the distributary system (network density, channel width, channel depth), and so enables generalizing results to real-world systems. We estimated the displacement magnitude range for real-world systems based on modern distributary network characteristics and historical displacement records from nearby faults (Figure 5, Supporting Information). Faulting-induced displacement measurements are uncommon, and some available measurements are not robustly documented (e.g., anecdotal), such that our displacement mag- nitude ranges are scaling estimates; additional faulting-induced subsidence data are needed to better constrain $\widehat{\sigma}$.

End-member deltaic configuration examples motivating this study bound scales of distributary network reorganization (Figure 5). For example, the Selenga River delta has a $\hat{\sigma}$ range indicative of substantial distributary network reorganization following large and periodic earthquake-related displacements, and the same should be expected for similarly scaled systems. At these scales, reorganization may be recorded in the chemical and sedimentary stratigraphy of the delta as unconformities and hierarchical packages that appear similar to autogenic avulsions (Dong et al., 2016; Ganti, Lamb, \& Chadwick, 2019; Ganti, Hajek, Leary, Straub, \& Paola, 2020). At the opposite spectrum end, the Mississippi River delta main-channel $\widehat{\sigma}$ range indicates negligible reorganization (Figure 5). Intuitively, reorganizing Mississippi-sized channels would require larger displacement than has been documented on the delta (Armstrong et al., 2014).

At the scale of sediment diversions planned on the Mississippi River delta, faulting-induced subsidence would drive distributary reorganization and restrict sediment dispersal (Figure 5). We use Cubit's Gap subdelta (Figure 1b; Esposito, Georgiou, \& Kolker, 2013) as a proxy for distributary network characteristics of planned Mississippi River delta diversions, and apply displacement measurements from nearby faults (Supporting Information). At these intermediate $\widehat{\sigma}$ scales, the distributary network response to faulting-induced subsidence is uncertain but potentially significant $\left(\Delta R_{Q_{s}} \approx 0.6\right.$; Figure 5$)$. For example, the upper range of displacement would partition sediment dispersal to fill newly-created accommodation (Figure 5), which in turn, would delay land building across the diversion site.

Cubit's Gap displacement magnitude estimates show how our scaling approach (i.e., Figure 5) can be used to assess faultinginduced subsidence hazard on deltas globally, but uncertainty on displacement likelihood prevents robust assessments of risk to land-building sediment diversions. Therefore, improved geotechnical evaluation downstream of diversion sites, coupled with ensemble modeling to assess potential variability in distributary network organization, is necessary to understand the probable range of land building scenarios at any specific site.

Validating models will require field-based flux partitioning observations from deltas (Dong et al., 2020). These data will support an understanding of delta response to perturbations generally, and promote sustainable landscape management (Passalacqua et al., 2021). In this context, we suggest targeting mapped fault locations with temporally-resolved morphodynamic and hydrodynamic measurements, thus providing a baseline for future faulting-induced subsidence scenarios. These data will also inform how diffusive processes not included in our model such as waves and tides, work to fill subaqueous topographic lows without channelized flow (e.g., Obelcz, Xu, Bentley, O'Connor, \& Miner, 2018). An important direction for future sediment diversion studies will be to model processes contributing to vertical land-surface movement, such as rapid relative sea-level rise, sediment compaction (Törnqvist et al., 2008), and organic matter accretion (Sanks et al., 2020). 


\section{DATA AVAILABILITY}

This study utilized open-source projects pyDeltaRCM (v1.2) and DeltaMetrics (v0.1). The project workflow is available on GitHub at https://github.com/amoodie/paper resources under folder "Moodie_faultingsubsidence". The GitHub repository includes scripts to configure and execute model runs, process and analyze data, and generate figures in this article. An archived version of source code and supplementary data will be deposited in a Zenodo repository if paper is accepted.

\section{ACKNOWLEDGMENTS}

This study was funded by the National Science Foundation, by way of a Postdoctoral Fellowship to A.M. (EAR-1952772) and a research grant to P.P. (EAR-1719670). We thank Tian Dong and David Mohrig for helpful discussions that sharpened ideas in this study, Brandee Carlson for providing feedback on an early version of this article, and two anonymous reviewers who improved the clarity and scope of our study. We also acknowledge Jayaram Hariharan, who was instrumental in implementing the numerical model and analysis tools used for this study.

\section{REFERENCES}

Armstrong, C., Mohrig, D., Hess, T., George, T., \& Straub, K. M. (2014). Influence of growth faults on coastal fluvial systems: Examples from the late miocene to recent mississippi river delta. Sedimentary Geology, 301, 120132. doi: 10.1016/j.sedgeo.2013.06.010

Army Corps of Engineers. (2021). Draft Mid-Barataria Sediment Diversion Project Environmental Impact Statement: Appendix E: Delft 3D Modeling (Tech. Rep.). Retrieved from https://www.mvn.usace.army - mil/Missions/Regulatory/Permits/ Mid-Barataria-Sediment-Diversion-EIS/

Bridge, J. S., \& Leeder, M. R. (1979, October). A simulation model of alluvial stratigraphy. Sedimentology, 26(5), 617644. doi: 10.1111/j.1365-3091.1979.tb00935.x

Chalov, S., Thorslund, J., Kasimov, N., Aybullatov, D., Ilyicheva, E., Karthe, D., ... Jarsjö, J. (2016, June). The Selenga River delta: a geochemical barrier protecting Lake Baikal waters. Regional Environmental Change, 17(7), 20392053. doi: 10.1007/s10113-016-0996-1

Chaplin-Kramer, R., Sharp, R. P., Weil, C., Bennett, E. M., Pascual, U., Arkema, K. K., .. . Daily, G. C. (2019). Global modeling of nature's contributions to people. Science, 366(6462), 255-258. doi: 10.1126/science.aaw3372

Culpepper, D., McDade, E. C., Dawers, N., Kulp, M., \& Zhang, R. (2019). Synthesis of fault traces in se louisiana relative to infrastructure. Retrieved from https://digitalcommons.lsu .edu/transet_data/30

Déverchére, J., Petit, C., Gileva, N., Radziminovitch, N., Melnikova, V., \& San'Kov, V. (2001, 09). Depth distribution of earthquakes in the Baikal rift system and its implications for the rheology of the lithosphere. Geophysical Journal International, 146(3), 714-730. doi: 10.1046/j.0956-540x.2001.1484.484.x
Dokka, R. K. (2006, 04). Modern-day tectonic subsidence in coastal Louisiana. Geology, 34(4), 281-284. doi: 10.1130/ G22264.1

Dokka, R. K. (2011). The role of deep processes in late 20th century subsidence of New Orleans and coastal areas of southern Louisiana and Mississippi. Journal of Geophysical Research: Solid Earth, 116(B6). doi: 10.1029/2010JB008008

Dong, T. Y. (2020). Dynamics of delta building across different scales as informed by the Selenga River Delta, Russia (Doctoral Dissertation, Rice University). Retrieved from https: / / scholarship.rice.edu/ handle/1911/108386

Dong, T. Y., Nittrouer, J. A., Il'icheva, E., Pavlov, M., McElroy, B., Czapiga, M. J., . . . Parker, G. (2016, March). Controls on gravel termination in seven distributary channels of the selenga river delta, baikal rift basin, russia. Geological Society of America Bulletin, 128(7-8), 1297-1312. doi: $10.1130 / \mathrm{b} 31427.1$

Dong, T. Y., Nittrouer, J. A., McElroy, B. J., Il'icheva, E., Pavlov, M., Ma, H., \& Moodie, A. J. (2020). Predicting water and sediment partitioning in a delta channel network under varying discharge conditions. Water Resources Research. doi: 10.1029/2020WR027199

Edmonds, D. A., Paola, C., Hoyal, D. C. J. D., \& Sheets, B. A. (2011). Quantitative metrics that describe river deltas and their channel networks. Journal of Geophysical Research: Earth Surface, 116(F4). doi: 10.1029/2010JF001955

Edrington, C. H. (2005). Long-term subsidence and compaction rates: A new model for the Michoud area, south Louisiana (MS Thesis). Louisiana State University.

Esposito, C. R., Georgiou, I. Y., \& Kolker, A. S. (2013). Hydrodynamic and geomorphic controls on mouth bar evolution. Geophysical Research Letters, 40(8), 1540-1545. doi: $10.1002 / \mathrm{grl} .50333$

Fisk, H. N. (1944). Geological investigation of the alluvial valley of the lower mississippi river. Mississippi River Commission.

Fossen, H. (2020). Chapter 8: Fault classification, fault growth and displacement. In N. Scarselli, J. Adam, D. Chiarella, D. G. Roberts, \& A. W. Bally (Eds.), Regional geology and tectonics (second edition) (Second Edition ed., p. 119147). Elsevier. doi: 10.1016/B978-0-444-64134-2.00007 $-9$

Gagliano, S. M., Kemp III, E. B., Wicker, K. M., \& Wiltenmuth, K. S. (2003). Active geological faults and land change in southeastern louisiana. Coastal Environments, Inc. (Prepared for U. S. Army Corps of Engineers)

Gagliano, S. M., Kemp III, E. B., Wicker, K. M., Wiltenmuth, K. S., \& Sabate, R. W. (2003). Neotectonic framework of southeast Louisiana and applications to coastal restoration. GCAGS/GCSSEPM Transactions, 53, 262-276.

Ganti, V., Hajek, E. A., Leary, K., Straub, K. M., \& Paola, C. (2020). Morphodynamic hierarchy and the fabric of the sedimentary record. Geophysical Research Letters, 47(14). doi: 10.1029/2020GL087921

Ganti, V., Lamb, M. P., \& Chadwick, A. J. (2019, 08). Autogenic erosional surfaces in fluvio-deltaic stratigraphy from floods, avulsions and backwater hydrodynamics. Journal of Sedimentary Research, 89(8), 815-832. doi: 10.2110/jsr.2019.40 
Gasparini, N. M., Fischer, G. C., Adams, J. M., Dawers, N. H., \& Janoff, A. M. (2016). Morphological signatures of normal faulting in low-gradient alluvial rivers in south-eastern louisiana, usa. Earth Surface Processes and Landforms, 41(5), 642-657. doi: 10.1002/esp.3852

Geller, R. J. (1997, 12). Earthquake prediction: a critical review. Geophysical Journal International, 131(3), 425-450. doi: 10.1111/j.1365-246X.1997.tb06588.X

Giosan, L., Constantinescu, S., Filip, F., \& Deng, B. (2013). Maintenance of large deltas through channelization: Nature vs. humans in the danube delta. Anthropocene, 1,35 - 45. doi: https://doi.org/10.1016/j.ancene.2013.09.001

Hajek, E. A., \& Edmonds, D. A. (2014, March). Is river avulsion style controlled by floodplain morphodynamics? Geology, 42(3), 199-202. doi: 10.1130/G35045.1

Heller, P. L., \& Paola, C. (1996, March). Downstream Changes In Alluvial Architecture: An Exploration of Controls on Channel-stacking Patterns. Journal of Sedimentary Research, 66(2), 297-306. doi: 10.1306/D4268333-2B26 $-11 \mathrm{D} 7-8648000102 \mathrm{C} 1865 \mathrm{D}$

Hickson, T. A., Sheets, B. A., Paola, C., \& Kelberer, M (2005, 07). Experimental test of tectonic controls on three-dimensional alluvial facies architecture. Journal of Sedimentary Research, 75(4), 710-722. doi: 10.2110/ jsr.2005.057

Hoitink, A., Nittrouer, J., Passalacqua, P., Shaw, J., Langendoen, E., Huismans, Y., \& van Maren, D. (2020). Resilience of river deltas in the anthropocene. Journal of Geophysical Research: Earth Surface. doi: 10.1029/2019JF005201

Il'icheva, Y. A., Pavlov, M. V., \& Korytny, L. M. (2014). The river network of the Selenga delta at present. Tomsk State University Journal, 380, 190-194. doi: 10.17223/ 15617793/380/32

Jerolmack, D. J., \& Mohrig, D. (2007). Conditions for branching in depositional rivers. Geology, 35(5), 463. doi: 10.1130/ G23308A.1

Jerolmack, D. J., \& Sadler, P. (2007). Transience and persistence in the depositional record of continental margins. Journal of Geophysical Research: Earth Surface, 112(F3). doi: 10.1029/2006JF000555

Kim, W., Mohrig, D., Twilley, R., Paola, C., \& Parker, G. (2009, October). Is It Feasible to Build New Land in the Mississippi River Delta? Eos, Transactions American Geophysical Union, 90(42), 373-374. doi: 10.1029/2009EO420001

Kim, W., Sheets, B. A., \& Paola, C. (2010). Steering of experimental channels by lateral basin tilting. Basin Research, 22(3), 286-301. doi: 10.1111/j.1365-2117.2009.00419.x

Kolb, C., \& Van Lopik, J. (1958). Geology of the Mississippi River deltaic plain, southeastern Louisiana. Waterways Experiment Station (US). Retrieved from https://usace.contentdm.oclc.org/ digital/collection/p266001coll1/id/ $3059 /$

Kolker, A. S., Miner, M. D., \& Weathers, H. D. (2012). Depositional dynamics in a river diversion receiving basin: The case of the west bay mississippi river diversion. Estuarine, Coastal and Shelf Science, 106, 1-12. doi: 10.1016/j.ecss.2012.04.005

Krivonogov, S., \& Safonova, I. (2017). Basin structures and sediment accumulation in the Baikal Rift Zone: Implications for Cenozoic intracontinental processes in the Central Asian Orogenic Belt. Gondwana Research, 47, 267-290. doi: 10.1016/j.gr.2016.11.009

Lauzon, R., \& Murray, A. B. (2018). Comparing the cohesive effects of mud and vegetation on delta evolution. Geophysical Research Letters, 45(19), 10,437-10,445. doi: 10.1029/2018GL079405

Lauzon, R., Piliouras, A., \& Rowland, J. C. (2019, June). Ice and permafrost effects on delta morphology and channel dynamics. Geophysical Research Letters. doi: 10.1029/ 2019GL082792

Leopold, L. B., Wolman, M. G., \& Miller, J. P. (1964). Fluvial processes in geomorphology. San Francisco: W.H. Freeman and Company.

Liang, M., Geleynse, N., Edmonds, D. A., \& Passalacqua, P. (2015b, January). A reduced-complexity model for river delta formation - Part 2: Assessment of the flow routing scheme. Earth Surface Dynamics, 3(1), 87-104. doi: 10.5194/esurf-3-87-2015

Liang, M., Kim, W., \& Passalacqua, P. (2016, October). How much subsidence is enough to change the morphology of river deltas?: DELTA RESPONSE TO REGIONAL SUBSIDENCE. Geophysical Research Letters, 43(19), 10,266-10,276. doi: 10.1002/2016GL070519

Liang, M., Van Dyk, C., \& Passalacqua, P. (2016, February). Quantifying the patterns and dynamics of river deltas under conditions of steady forcing and relative sea level rise: QUANTIFYING DELTA PATTERNS AND DYNAMICS Journal of Geophysical Research: Earth Surface, 121(2), 465-496. doi: 10.1002/2015JF003653

Liang, M., Voller, V. R., \& Paola, C. (2015a, January). A reduced-complexity model for river delta formation - Part 1: Modeling deltas with channel dynamics. Earth Surface Dynamics, 3(1), 67-86. doi: 10.5194/esurf-3-67-2015

Meckel, T. A., ten Brink, U. S., \& Williams, S. J. (2006). Current subsidence rates due to compaction of holocene sediments in southern louisiana. Geophysical Research Letters, 33(11). doi: 10.1029/2006GL026300

Mohrig, D., Heller, P. L., Paola, C., \& Lyons, W. J. (2000). Interpreting avulsion process from ancient alluvial sequences: Guadalope-Matarranya system (northern Spain) and Wasatch Formation (western Colorado). Geological Society of America Bulletin, 112(12), 1787-1803.

Moodie, A. J., Hariharan, J., Barefoot, E., \& Passalacqua, P. (2021). pyDeltaRCM: a flexible numerical delta model. Journal of Open Source Software. doi: 10.21105/joss .03398

Morton, R. A., \& Bernier, J. C. (2010). Recent subsidence-rate reductions in the mississippi delta and their geological implications. Journal of Coastal Research, 26(3), 555561. doi: 10.2307/40605484

Mouslopoulou, V., Walsh, J. J., \& Nicol, A. (2009). Fault displacement rates on a range of timescales. Earth and Planetary Science Letters, 278(3), 186-197. doi: 10.1016/ j.eps1.2008.11.031

Nienhuis, J. H., Ashton, A. D., Edmonds, D. A., Hoitink, A. J. F., Kettner, A. J., Rowland, J. C., \& Törnqvist, T. E. (2020, January). Global-scale human impact on delta morphology has led to net land area gain. Nature, 577(7791), 514-518. Retrieved 2020-0225, from http://www. nature.com/articles/ 
S41586-019-1905-9 $-1905-9$

doi: $10.1038 / \mathrm{s} 41586-019$

Nienhuis, J. H., Törnqvist, T. E., Jankowski, K. L., Fernandes, A. M., \& Keogh, M. E. (2017, June). A new subsidence map for coastal louisiana. GSA Today, 60-61. doi: 10 $.1130 /$ gsatg $337 \mathrm{gw} .1$

Nittrouer, J. A., Best, J. L., Brantley, C., Cash, R. W., Czapiga, M., Kumar, P., \& Parker, G. (2012, July). Mitigating land loss in coastal Louisiana by controlled diversion of Mississippi River sand. Nature Geoscience, 5(8), 534 537. doi: $10.1038 /$ ngeo 1525

Nittrouer, J. A., \& Viparelli, E. (2014, April). Sand as a stable and sustainable resource for nourishing the Mississippi River delta. Nature Geoscience, 7(5), 350-354. doi: 10.1038/ngeo2142

Obelcz, J., Xu, K., Bentley, S. J., O’Connor, M., \& Miner, M. D. (2018). Mud-capped dredge pits: An experiment of opportunity for characterizing cohesive sediment transport and slope stability in the northern Gulf of Mexico. Estuarine, Coastal and Shelf Science, 208, 161-169. doi: 10.1016/j.ecss.2018.04.039

Orlov, A. (1872). General remarks on earthquakes, with special reference to South Siberia and Turkestan Region. Proceedings of the Kazan University Society of Natural Science, 3. (in Russian)

Paola, C., Twilley, R. R., Edmonds, D. A., Kim, W., Mohrig, D., Parker, G., ... Voller, V. R. (2011, January). Natural Processes in Delta Restoration: Application to the Mississippi Delta. Annual Review of Marine Science, 3(1), 67-91. doi: 10.1146/annurev-marine-120709-142856

Passalacqua, P., Giosan, L., Goodbred, S., \& Overeem, I. (2021). Stable $\neq$ sustainable: Delta dynamics versus the human need for stability. Earth's Future, 9. doi: $10.1029 / 2021 \mathrm{EF} 002121$

Peyronnin, N., Green, M., Richards, C. P., Owens, A., Reed, D., Chamberlain, J., ... Belhadjali, K. (2013, July). Louisiana's 2012 Coastal Master Plan: Overview of a Science-Based and Publicly Informed Decision-Making Process. Journal of Coastal Research, 67, 1-15. doi: 10.2112/SI_67_1.1

Piliouras, A., Lauzon, R., \& Rowland, J. C. (2021). Unraveling the combined effects of ice and permafrost on arctic delta morphodynamics. Journal of Geophysical Research: Earth Surface, 126(4). doi: 10.1029/2020JF005706

Reitz, M. D., \& Jerolmack, D. J. (2012, May). Experimental alluvial fan evolution: Channel dynamics, slope controls, and shoreline growth. Journal of Geophysical Research, 117(F2). doi: 10.1029/2011JF002261

Reitz, M. D., Jerolmack, D. J., \& Swenson, J. B. (2010, March). Flooding and flow path selection on alluvial fans and deltas: FLOW PATH SELECTION ON ALLUVIAL FANS. Geophysical Research Letters, 37(6), n/a-n/a. doi: 10.1029/2009GL041985

Reitz, M. D., Pickering, J. L., Goodbred, S. L., Paola, C., Steckler, M. S., Seeber, L., \& Akhter, S. H. (2015). Effects of tectonic deformation and sea level on river path selection: Theory and application to the GangesBrahmaputra-Meghna River Delta. Journal of Geophys ical Research: Earth Surface, 120(4), 671-689. doi: 10.1002/2014JF003202

Roberts, H. H. (1997). Dynamic changes of the holocene missis- sippi river delta plain: The delta cycle. Journal of Coastal Research, 13(3), 605-627. doi: 10.2307/4298659

Sanks, K. M., Shaw, J. B., \& Naithani, K. (2020). Fieldbased estimate of the sediment deficit in coastal louisiana. Journal of Geophysical Research: Earth Surface, 125(8). doi: 10.1029/2019JF005389

Shaw, J. B., Wolinsky, M. A., Paola, C., \& Voller, V. R. (2008). An image-based method for shoreline mapping on complex coasts. Geophysical Research Letters, 35(12). doi: 10.1029/2008GL033963

Shchetnikov, A., Radziminovich, Y., Vologina, E., \& Ufimtsev, G. (2012). The formation of Proval Bay as an episode in the development of the Baikal rift basin: A case study. Geomorphology, 177-178, 1-16. doi: 10.1016/j.geomorph .2012.07.023

Shirzaei, M., Freymueller, J., Törnqvist, T. E., Galloway, D. L., Dura, T., \& Minderhoud, P. S. J. (2020, December). Measuring, modelling and projecting coastal land subsidence. Nature Reviews Earth \& Environment, 2(1), 40-58. doi: 10.1038/s43017-020-00115-X

Slingerland, R., \& Smith, N. D. (2004, May). RIVER AVULSIONS AND THEIR DEPOSITS. Annual Review of Earth and Planetary Sciences, 32(1), 257-285. doi: 10.1146/annurev.earth.32.101802.120201

Straub, K. M., \& Esposito, C. R. (2013, June). Influence of water and sediment supply on the stratigraphic record of alluvial fans and deltas: Process controls on stratigraphic completeness: STRATIGRAPHIC COMPLETENESS OF DELTAS. Journal of Geophysical Research: Earth Surface, 118(2), 625-637. doi: 10.1002/jgrf.20061

Swenson, J. B., Voller, V. R., Paola, C., Parker, G., \& Marr, J. (2000). Fluvio-deltaic sedimentation: A generalized Stefan problem. European Journal of Applied Mathematics, $11,433-452$.

Temmerman, S., \& Kirwan, M. L. (2015). Building land with a rising sea. Science, 349(6248), 588-589. doi: 10.1126/ science.aac 8312

Törnqvist, T. E., Wallace, D. J., Storms, J. E. A., Wallinga, J., van Dam, R. L., Blaauw, M., ... Snijders, E. M. A. (2008, February). Mississippi Delta subsidence primarily caused by compaction of Holocene strata. Nature Geoscience, 1(3), 173-176. doi: 10.1038/ngeo129

Vologina, E., Kalugin, I., Osukhovskaya, Y., Sturm, M., Ignatova, N., Radziminovich, Y., ... Kuz'min, M. (2010). Sedimentation in Proval Bay (Lake Baikal) after earthquakeinduced subsidence of part of the Selenga River delta. Russian Geology and Geophysics, 51(12), 1275-1284. doi: 10.1016/j.rgg.2010.11.008

Zeisler-Vralsted, D. (2019, January). African Americans and the Mississippi River: Race, history and the environment. Thesis Eleven, 150(1), 81-101. doi: 10.1177/ 0725513618822010 


\section{Supporting Information for: \\ When does faulting-induced subsidence drive distributary network reorganization?}

Andrew J. Moodie ${ }^{1}$ and Paola Passalacqua ${ }^{1}$

\section{Contents of this file}

1. Text $\mathrm{S} 1$ to $\mathrm{S} 2$

2. Figures $\mathrm{S} 1$ to $\mathrm{S} 5$

3. Table S1

${ }^{1}$ Department of Civil, Architectural and Environmental Engineering, University of Texas at Austin, Austin, Texas, 78712 


\section{S1. Additional methods description}

\section{S1.1. Mass balance into Selenga River delta eastern lobe following 1862 earthquake}

A compelling example of distributary network reorganization due to faulting-induced subsidence comes from the Selenga River delta (Russia). The Selenga River delta is situated along the margin of Lake Baikal, a lake bounded by tectonically active intracontinental rift-basin faults (Figure 1a; Déverchére et al., 2001; Krivonogov \& Safonova, 2017). The modern delta channel network divides into three distinct deltaic lobes (Figure 1a; Il'icheva et al., 2014), that each receive a moderate proportion of the water and sediment entering the delta (25-50\% each; Figure 1a; Dong et al., 2020; Dong, 2020).

An earthquake in 1862 induced up to $9 \mathrm{~m}$ of vertical land subsidence along the eastern delta edge (Orlov, 1872), lowering more than $230 \mathrm{~km}^{2}$ of land below the water surface and creating Proval Bay (Figure 1a; Vologina et al., 2010; Shchetnikov et al., 2012); lowered land comprised unconsolidated Quaternary and older Tsagan Steppe deposits (Shchetnikov et al., 2012). As a result, the shortest path from delta apex to lake level was available via Proval Bay (i.e., the eastern delta lobe). A bathymetric survey of Proval Bay following the earthquake indicated 1-5 $\mathrm{m}$ water depth centrally, and shallower 0.7-1.5 $\mathrm{m}$ depth proximal to the delta front (Orlov, 1872). In the $\sim 160$ years since, the shoreline along the eastern lobe (i.e., at Proval Bay) has prograded faster than elsewhere along the delta front (Dong, 2020), and has reached a condition that restores delta planform radial symmetry.

We are not aware of historical maps providing adequate temporal resolution to quantify distributary network reorganization following the earthquake. Instead, we apply a mass balance framework, including uncertainty via Monte Carlo sampling (number of samples $n=1000$ ), to indirectly discern whether reorganization was likely following the earthquake. We use published data and measurements from modern satellite imagery to determine that the Selenga River delta distributary network very likely reorganized, with water and sediment flux focused in the eastern delta lobe, following the 1862 earthquake. The following paragraphs elaborate on the approach, and mass-balance input parameter distributions.

The volume filled by sediment in the $\sim 160$ years since the earthquake was determined by multiplying an estimated deposit area $\left(D_{A}\right)$ by an estimated deposit thickness $\left(D_{Z}\right)$. For $D_{A}$, we used the areal extent between the modern shoreline and the shoreline as mapped in $\sim 1862$ (Dong, 2020), and determined $D_{A}=67.1 \pm 12.0 \mathrm{~km}^{2}$ (Figure S1a); we assessed areal uncertainty by mapping the polygon at varied resolutions. We then used this polygon to constrain the area over which to estimate deposit thickness. Deposit thickness was determined as the water depth immediately following the earthquake (i.e., ignoring effects of delta or basin slope); measurements of Proval Bay water depth are determined from data published in Vologina et al. (2010) and originally derived from Orlov (1872). These measurements describe depth range in Proval Bay proximal to the delta front $0.7-1.5 \mathrm{~m}$, and the mean and standard deviation used for the mass balance of $D_{Z}=1.1 \pm 0.3 \mathrm{~m}$ (Figure $\mathrm{S} 1 \mathrm{~b}$ ). Together, estimated deposit areal extent and thickness yield a volumetric sediment deposit $D_{V}=6.8 \pm 2.1 \times 10^{7} \mathrm{~m}^{3}$ to the eastern delta lobe in a duration $D_{T}=150-160$ years; we used $D_{T} \sim \mathscr{U}(150,160)$ for Monte Carlo samples.

Sediment flux to the delta has likely varied over the last century, and is poorly constrained (e.g., Chalov et al., 2016). We used an estimate of bed-material load from Dong (2020) of $Q_{b m}=2.35 \pm 0.22 \times 10^{5} \mathrm{~m}^{3} / \mathrm{yr}$ for annual sediment input to the delta. For simplicity, we used a fixed depositional porosity $\phi=0.25$ (Leopold et al., 1964). We also applied a fixed constant 
of proportionality to account for compaction of deposited sediments $\left(\sigma_{c}\right)$, assuming that up to $35 \%$ of the sediment volume was reduced by compaction (after Törnqvist et al., 2008).

We define a governing mass-balance equation for a single deltaic lobe as:

$$
\left(1-\sigma_{c}\right)(1-\phi) V=F Q_{b m} T
$$

where $V$ is deposit volume, $T$ is a time duration, and $F$ is the fraction of sediment input to the delta that is partitioned to the deltaic lobe of interest.

Equation S1 can be rearranged and solved with different constraints. In the second row of Figure $\mathrm{S} 1$ (d-f), we set $V$ equal to $D_{V}$ and solved for $T$, varying the sediment partitioning to assess how much time would be required to reproduce the observed sediment volume. We varied the present delta partitioning according to the modern partitioning $F=0.23$ (23\% to eastern lobe), equal delta partitioning $F=0.33$ (33\% to eastern lobe), or focused delta partitioning $F=1.0$ (100\% to eastern lobe). The third row of Figure $\mathrm{S} 1$ (g-i) depicts the results discussed in the introduction of the main text, where we solved Equation $\mathrm{S} 1$ for $V$ and taking a ratio $V / D_{V}$, while setting $T \sim D_{T}$ and varying delta partitioning as $F=0.23,0.33$, and 1.0.

Finally, we determined the flux partitioning needed to produce the observed deposit volume by setting $T \sim D_{T}$ and $V=D_{V}$ and solving for $F$. From this calculation, we determine that 95$189 \%$ of the sediment input to the delta is needed to reproduce the observed record. Therefore, and in conjunction with highly asymmetric shoreline progradation (Dong, 2020), we infer that it is very likely that substantial distributary network reorganization occurred following the 1862 earthquake on the Selenga River delta.

\section{S1.2. Simulation pyDeltaRCM parameters}

Set 1 and Set 2 parameters are highlighted in Table S1.

Model parameter sets identified by previous studies informed boundary conditions chosen for Set 1 and Set 2 simulations (Liang et al., 2015a; Liang, Van Dyk, \& Passalacqua, 2016; Liang, Kim, \& Passalacqua, 2016). To qualitatively match the Selenga River delta with Set 1 simulations, we imposed a relatively high proportion of sand input to the delta (55\%) (Liang et al., 2015a) and maintained a moderate basin depth at $5 \mathrm{~m}$. High sand proportion coupled with fixed sea level produced an approximately radially symmetric delta planform with local embayments around former distributary channels (Figure 2a). In Set 2 simulations configured to qualitatively match the Mississippi River delta, we imposed a low proportion of sand input (35\%), slow sea level rise at $2 \mathrm{~mm} / \mathrm{yr}$, and a deep basin at $10 \mathrm{~m}$ (Figure 2b). Together, these parameters led to a condition that drowned inter-distributary bays between avulsions (Figure 2b). Additional parameters (Table S1) scaled the Set 1 and Set 2 deltas and influenced the size of channels.

\section{S1.3. Graphical depiction of metrics}

This Section includes graphical depictions of the metrics (equations) described in described in the main text Section 4 (Figure S2). Figure S2a shows a simulation from Set $1\left(H_{\sigma}=2\right)$ immediately following the displacement event.

We define delta length asymmetry $\left(R_{r}\right)$ as:

$$
R_{r}=\frac{r_{\sigma}}{r}
$$


(i.e., Equation 3) where $r_{\sigma}$ and $r$ are the mean Euclidean distance from delta apex to points along the shoreline within the subsided block and across the entire delta, respectively. Figure S2b depicts the shoreline as determined by the Opening Angle method (Shaw et al., 2008), setting the shoreline contour threshold to $75^{\circ}$. Given the set of cells along the shoreline $I$ and a set of cells coincident with the subsided block $S$, we find the shoreline cells inside the subsided block $I_{S}=I \cap S$ (darker shoreline segments in Figure S2b) and other shoreline points $I_{X}$ (lighter shoreline segments in Figure $\mathrm{S} 2 \mathrm{~b}$ ). Then, $r_{\sigma}$ and $r$ are calculated as:

$$
\begin{aligned}
& r_{\sigma}=\frac{1}{\left|I_{S}\right|} \sum_{i \in\left\{1,2, \ldots,\left|I_{S}\right|\right\}}^{\left|I_{S}\right|} \sqrt{\left(x_{i}-x_{0}\right)^{2}+\left(y_{i}-y_{0}\right)^{2}} \\
& r=\frac{1}{\left|I_{X}\right|} \sum_{i \in\left\{1,2, \ldots,\left|I_{X}\right|\right\}}^{\left|I_{X}\right|} \sqrt{\left(x_{i}-x_{0}\right)^{2}+\left(y_{i}-y_{0}\right)^{2}}
\end{aligned}
$$

where $\left|I_{S}\right|$ and $\left|I_{X}\right|$ are the length of sets $I_{S}$ and $I_{X}, x_{i}$ and $y_{i}$ are the $x$ - and $y$-coordinate of the $i^{\text {th }}$ index in the set, and $x_{0}$ and $y_{0}$ are the $x$ - and $y$-coordinate of the delta inlet.

Figure S2c shows the circular section used for computing the flux asymmetry metric, which we define in the main text Section 4 as:

$$
R_{Q_{s}}=\frac{Q_{s, \sigma}}{Q_{s}}
$$

(i.e., Equation 4) where $Q_{s, \sigma}$ and $Q_{s}$ are the sediment flux into the subsided block and across the delta, respectively. We computed $Q_{s, \sigma}$ and $Q_{s}$ as:

$$
\begin{aligned}
Q_{s, \sigma} & =\int_{B}^{C} q_{s} d s \\
Q_{s} & =\int_{A}^{D} q_{s} d s
\end{aligned}
$$

where $q_{s}$ is the unit-cell directed sediment discharge $\left(\mathrm{m}^{2} / \mathrm{s}\right)$, and $\{A, B, C, D\}$ are ordered points defined on the along-section coordinate $s$ of the circular section (Figure S2c). The definite integral was evaluated numerically via the trapezoidal rule.

Finally, the subaerial delta land area $\left(A_{L}\right)$ was quantified as:

$$
A_{L}=\sum_{i=1}^{L} \sum_{j=1}^{W} A_{i j}
$$

(i.e., Equation 1) where $i$ and $j$ are model cell indices, $L$ and $W$ are the number of cells in each dimension of the model domain, and

$$
A_{i j}=\left\{\begin{array}{ll}
d x^{2} & : \eta_{i j}>H_{W L} \\
0 & : \eta_{i j} \leq H_{W L}
\end{array},\right.
$$

(i.e., Equation 2) where $d x$ is the model grid cell size, $\eta$ is the bed elevation, and $H_{W L}$ is the basin water level elevation. Figure S2d shows the area of subaerial land by covering the excluded area 
with a black shading. Note that channels are usually excluded from the calculated subaerial land, because the bed elevation in these locations is below water level (Equation S9).

\section{S1.4. Estimating displacement magnitude for real-world deltas}

We estimated the displacement magnitude $(\widehat{\sigma})$ for real-world deltaic systems using data from along a cross section placed approximately halfway between the delta apex and coast (Figure S3). We acknowledge that this placement is somewhat arbitrary, given that our study identifies the importance of fault location with respect to the channel network. However, we expect that placement in the central delta will yield representative displacement magnitude values.

We measured the fraction of delta width channelized from Sentinel 2 imagery collected in 2020 and 2021 for the Selenga and Mississippi River deltas, respectively (Figure S3). Using this imagery, we identified channelized lengths along the cross section, and then simply computed the fractional length channelized $\left(F_{w}\right)$.

To estimate displacement magnitude for the Selenga River delta system, we extracted channel measurements from Dong et al. (2019) yielding a minimum and maximum width $62 \mathrm{~m}$ and $205 \mathrm{~m}$ and depth $1.1 \mathrm{~m}$ and $2.7 \mathrm{~m}$ located approximately at the identified cross section (Figure S3a). Selenga River delta displacement measurements were obtained from a 1862 earthquake with fault width $9650 \mathrm{~m}$ and displacement length ranging 2-5 m (Orlov, 1872). These measurements yield a displacement magnitude range of 1.0-21.1.

We made two displacement magnitude estimates for the Mississippi River delta system, based on channel geometries of the main river channel and the Cubit's Gap subdelta. Misssissipi River main channel geometry was constrained from river-cross sectional data in Nittrouer, Allison, and Campanella (2008); Nittrouer et al. (2012) ranging width 900-930 m and depth 25-35 m, and Cubit's Gap channel geometries were obtained from Esposito, Georgiou, and Kolker (2013) as width 70-155 $\mathrm{m}$ and depth 3.2-7.2 $\mathrm{m}$. Faulting-induced subsidence displacement data are sparse and variable in the Mississippi River delta, so we have attempted to bracket a range of plausible displacements, emphasizing the need to inform potential hazards to land building. Fault width for the Empire and Bastian Bay are estimated at $10570 \mathrm{~m}$ and $8560 \mathrm{~m}$, respectively (Gagliano et al., 2003; Culpepper et al., 2019). Anecdotal displacement lengths ranging 0.9$1.4 \mathrm{~m}$ have been reported by delta residents (Gagliano et al., 2003), have been estimated using total Holocene displacement as $0.3 \mathrm{~m}$, and a direct measurement reported is $0.2 \mathrm{~m}$ from Fisk (1944). Applying these measurements yield displacement magnitude 7.2-91.2 $\times 10^{-4}$ for the main channel, and 0.03-1.39 for a distributary system scaled like Cubit's Gap.

Channel geometry and network data are compiled in a spreadsheet available within the Github repository https://github.com/amoodie/paper_resources under folder "Moodie_faultingsubsidence". Shapefiles for measurements of fraction channelized delta width are also included there.

\section{S2. Selected simulation results}

In this section we include planform view of the bed morphology and water discharge field following displacement, from selected representative model simulations. Selected simulations from Experiment Set 1 depict the range of behavior in reorganization following displacement, as well as how soft avulsion maintains multiple active distributary channels across the delta topset. Selected simulations from Experiment Set 2 show how reorganization depends on "con- 
nectedness" (see main text), and the nature of lobe-switching avulsions in this experimental set. See Figure S4 and S5 captions for detailed description.

\section{References}

Chalov, S., Thorslund, J., Kasimov, N., Aybullatov, D., Ilyicheva, E., Karthe, D., .. Jarsjö, J. (2016, June). The Selenga River delta: a geochemical barrier protecting Lake Baikal waters. Regional Environmental Change, 17(7), 2039-2053. doi: 10.1007/s10113-016 -0996-1

Culpepper, D., McDade, E. C., Dawers, N., Kulp, M., \& Zhang, R. (2019). Synthesis of fault traces in se louisiana relative to infrastructure. Retrieved from https:// digitalcommons.lsu.edu/transet_data/30

Déverchére, J., Petit, C., Gileva, N., Radziminovitch, N., Melnikova, V., \& San'Kov, V. (2001, 09). Depth distribution of earthquakes in the Baikal rift system and its implications for the rheology of the lithosphere. Geophysical Journal International, 146(3), 714-730. doi: 10.1046/j.0956-540x.2001.1484.484.x

Dong, T. Y. (2020). Dynamics of delta building across different scales as informed by the Selenga River Delta, Russia (Doctoral Dissertation, Rice University). Retrieved from https://scholarship.rice.edu/handle/1911/108386

Dong, T. Y., Nittrouer, J. A., Czapiga, M. J., Ma, H., McElroy, B., Il'icheva, E., ... Parker, G. (2019, January). Roles of Bank Material in Setting Bankfull Hydraulic Geometry as Informed by the Selenga River Delta, Russia. Water Resources Research, 55(1), 827-846. doi: 10.1029/2017WR021985

Dong, T. Y., Nittrouer, J. A., McElroy, B. J., Il'icheva, E., Pavlov, M., Ma, H., \& Moodie, A. J. (2020). Predicting water and sediment partitioning in a delta channel network under varying discharge conditions. Water Resources Research. doi: 10.1029/2020WR027199

Esposito, C. R., Georgiou, I. Y., \& Kolker, A. S. (2013). Hydrodynamic and geomorphic controls on mouth bar evolution. Geophysical Research Letters, 40(8), 1540-1545. doi: $10.1002 /$ grl.50333

Fisk, H. N. (1944). Geological investigation of the alluvial valley of the lower mississippi river. Mississippi River Commission.

Gagliano, S. M., Kemp III, E. B., Wicker, K. M., \& Wiltenmuth, K. S. (2003). Active geological faults and land change in southeastern louisiana. Coastal Environments, Inc. (Prepared for U. S. Army Corps of Engineers)

Il'icheva, Y. A., Pavlov, M. V., \& Korytny, L. M. (2014). The river network of the Selenga delta at present. Tomsk State University Journal, 380, 190-194. doi: 10.17223/15617793/ $380 / 32$

Krivonogov, S., \& Safonova, I. (2017). Basin structures and sediment accumulation in the Baikal Rift Zone: Implications for Cenozoic intracontinental processes in the Central Asian Orogenic Belt. Gondwana Research, 47, 267-290. doi: 10.1016/j.gr.2016.11.009

Leopold, L. B., Wolman, M. G., \& Miller, J. P. (1964). Fluvial processes in geomorphology. San Francisco: W.H. Freeman and Company.

Liang, M., Kim, W., \& Passalacqua, P. (2016, October). How much subsidence is enough 
to change the morphology of river deltas?: DELTA RESPONSE TO REGIONAL SUBSIDENCE. Geophysical Research Letters, 43(19), 10,266-10,276. doi: 10.1002/ 2016GL070519

Liang, M., Van Dyk, C., \& Passalacqua, P. (2016, February). Quantifying the patterns and dynamics of river deltas under conditions of steady forcing and relative sea level rise: QUANTIFYING DELTA PATTERNS AND DYNAMICS. Journal of Geophysical Research: Earth Surface, 121(2), 465-496. doi: 10.1002/2015JF003653

Liang, M., Voller, V. R., \& Paola, C. (2015a, January). A reduced-complexity model for river delta formation - Part 1: Modeling deltas with channel dynamics. Earth Surface Dynamics, 3(1), 67-86. doi: 10.5194/esurf-3-67-2015

Nittrouer, J. A., Allison, M. A., \& Campanella, R. (2008, July). Bedform transport rates for the lowermost Mississippi River. Journal of Geophysical Research, 113(F3). doi: 10.1029/2007JF000795

Nittrouer, J. A., Best, J. L., Brantley, C., Cash, R. W., Czapiga, M., Kumar, P., \& Parker, G. (2012, July). Mitigating land loss in coastal Louisiana by controlled diversion of Mississippi River sand. Nature Geoscience, 5(8), 534-537. doi: 10.1038/ngeo1525

Orlov, A. (1872). General remarks on earthquakes, with special reference to South Siberia and Turkestan Region. Proceedings of the Kazan University Society of Natural Science, 3. (in Russian)

Reitz, M. D., Jerolmack, D. J., \& Swenson, J. B. (2010, March). Flooding and flow path selection on alluvial fans and deltas: FLOW PATH SELECTION ON ALLUVIAL FANS. Geophysical Research Letters, 37(6), n/a-n/a. doi: 10.1029/2009GL041985

Shaw, J. B., Wolinsky, M. A., Paola, C., \& Voller, V. R. (2008). An image-based method for shoreline mapping on complex coasts. Geophysical Research Letters, 35(12). doi: 10.1029/2008GL033963

Shchetnikov, A., Radziminovich, Y., Vologina, E., \& Ufimtsev, G. (2012). The formation of Proval Bay as an episode in the development of the Baikal rift basin: A case study. Geomorphology, 177-178, 1-16. doi: 10.1016/j.geomorph.2012.07.023

Törnqvist, T. E., Wallace, D. J., Storms, J. E. A., Wallinga, J., van Dam, R. L., Blaauw, M., ... Snijders, E. M. A. (2008, February). Mississippi Delta subsidence primarily caused by compaction of Holocene strata. Nature Geoscience, 1(3), 173-176. doi: 10.1038/ngeo129

Vologina, E., Kalugin, I., Osukhovskaya, Y., Sturm, M., Ignatova, N., Radziminovich, Y., ... Kuz'min, M. (2010). Sedimentation in Proval Bay (Lake Baikal) after earthquake-induced subsidence of part of the Selenga River delta. Russian Geology and Geophysics, 51(12), 1275-1284. doi: 10.1016/j.rgg.2010.11.008 

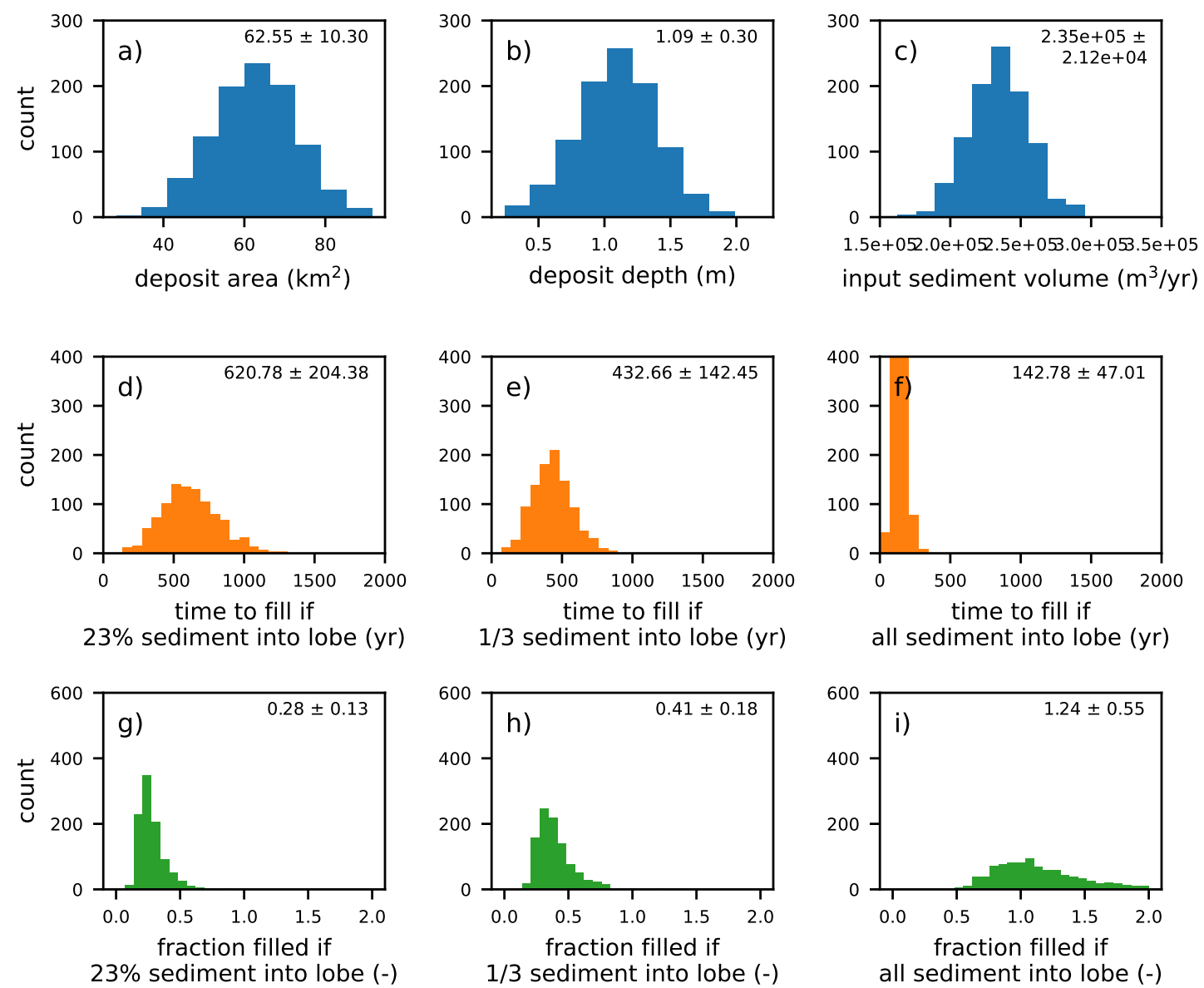

Figure S1. Mass balance framework inputs and results; distributions represent samples from Monte Carlo assessment with $n=1000$ samples. Inputs to mass balance framework a) deposit area and b) deposit thickness. d-f) Results from solving Equation S1 for time needed to reproduce the deposit for different sediment partitioning fractions. g-i) Results from solving Equation S1 for fraction of observed deposited volume that would be deposited over historical record duration for different sediment partitioning fractions. 

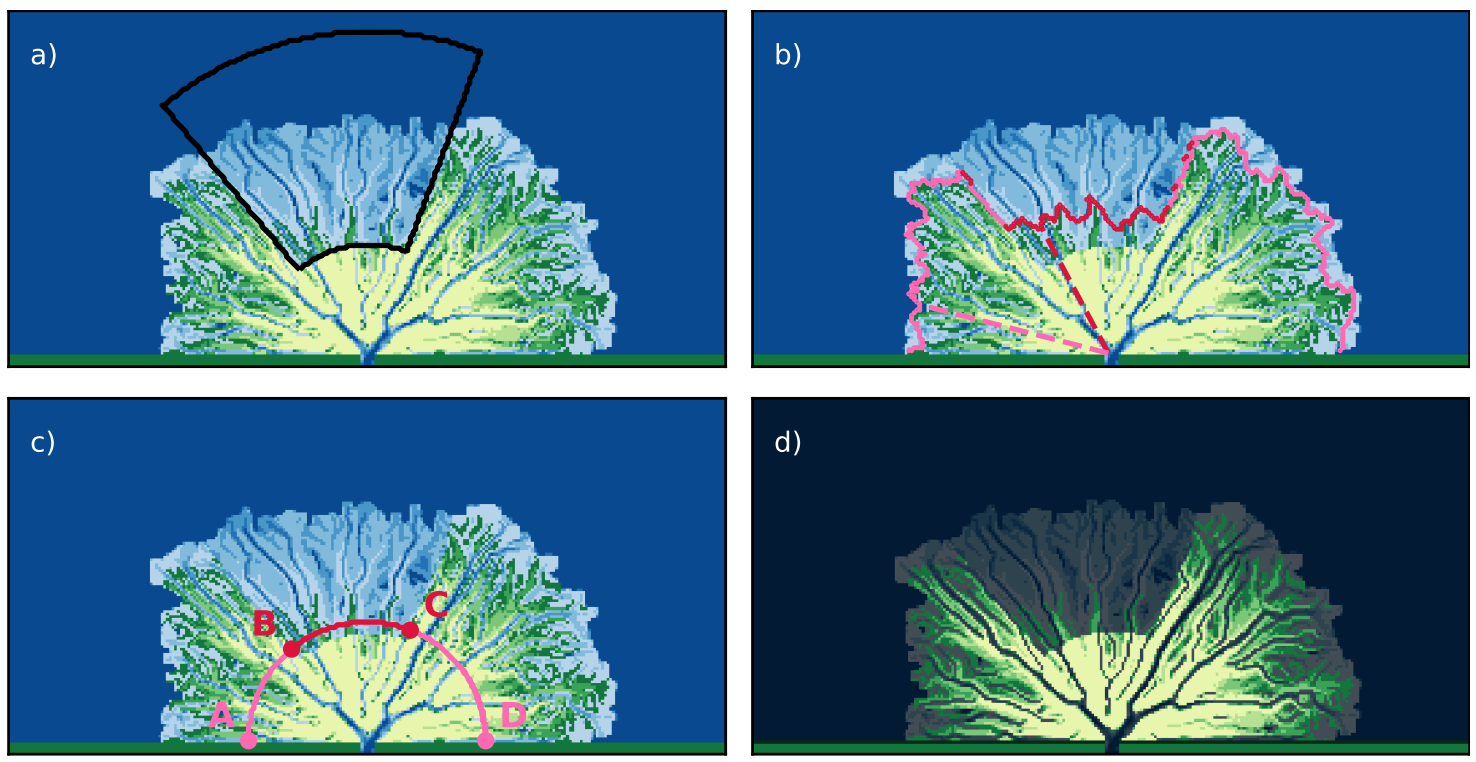

Figure S2. Graphical depiction of a) planform delta morphology following displacement, and metrics computed in main text (b-d). b) Shoreline identified by the Opening Angle Method (Shaw et al., 2008), split into segments within the subsided block (dark pink) and elsewhere along the delta (light pink); i.e., depiction of Equation 3. c) Circular cross section along fault for sediment flux asymmetry, where flux to subsided block is computed along section between points $\mathrm{B}$ and $\mathrm{C}$ (dark pink), and delta-wide flux is computed along section between points A and D (light pink); i.e., depiction of Equation 4. d) Subaerial delta area depicted with areas where the bed elevation is below the water level; i.e., depiction of Equation 2. 

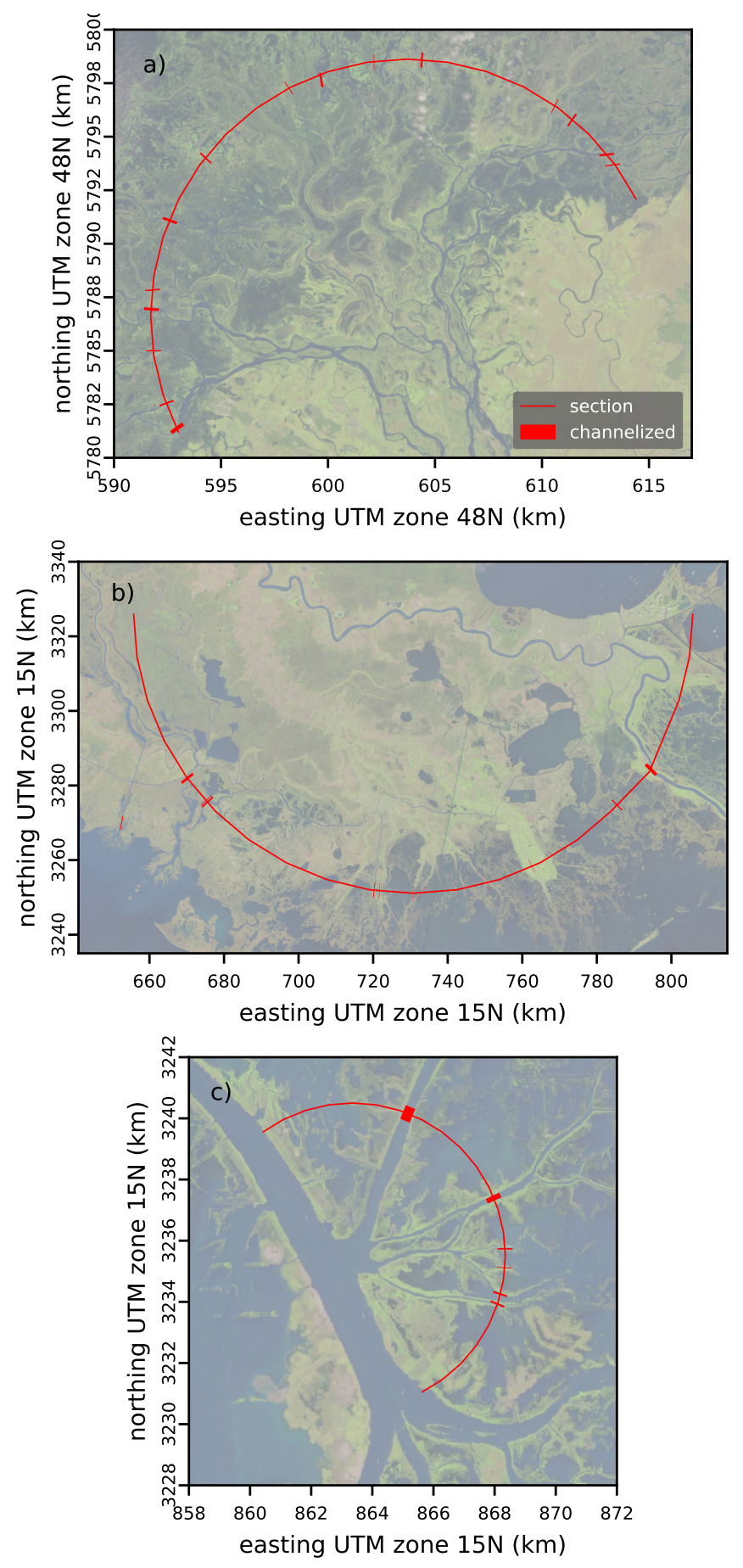

Figure S3. Depiction of sections and channel width measurements used to determine $F_{w}$ for field sites a) the Selenga River delta, b) the Mississippi River delta, and c) the Cubit's Gap subdelta within the Mississippi River delta. Underlying maps have been lightened to highlight the channelized-flow locations measurements. 

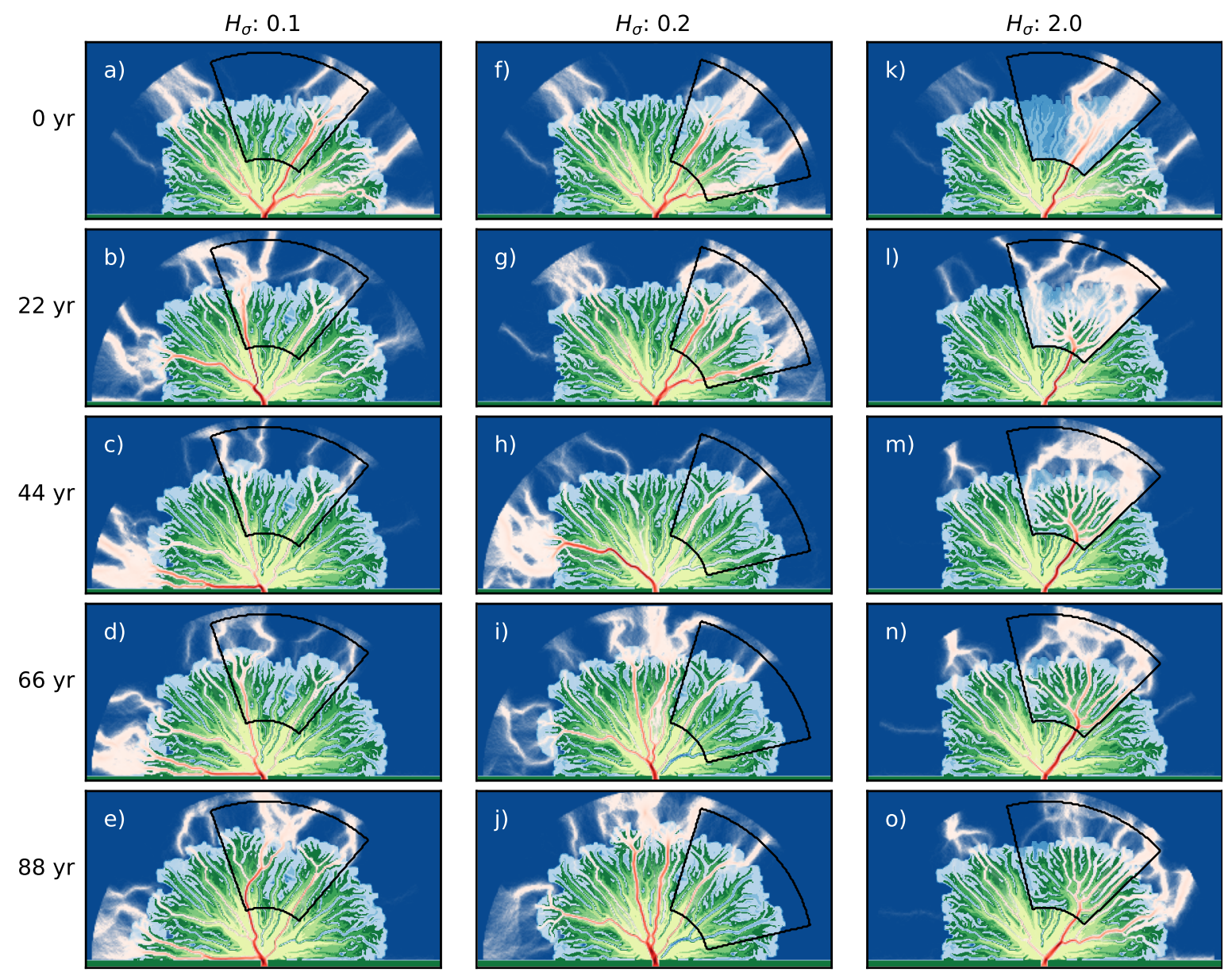

Figure S4. Planform evolution of the bed morphology and water discharge field following displacement for selected simulations from Experiment Set 1. In simulation depicted in first column (a-e), displacement length is relatively small and does not induce reorganization. Several soft avulsions occur throughout the $88 \mathrm{yr}$ period; note that multiple distributary outlets remain active at all times. Simulation depicted in second column $(\mathrm{f}-\mathrm{j})$ exemplifies the subtle reorganization induced by a moderate displacement length. For $\sim 44$ yr, flow is towards the subsided region, before avulsion relocates the bulk of the water discharge. Simulation depicted in third column $(\mathrm{k}-\mathrm{o})$ exemplifies the most extreme case, where displacement length is large, and water discharge is focused in the subsided region for the duration of the simulation. Sediment discharge follows water discharge, and a sub-delta builds within the bay created by displacement; at the end of the simulation, the delta is symmetric. 

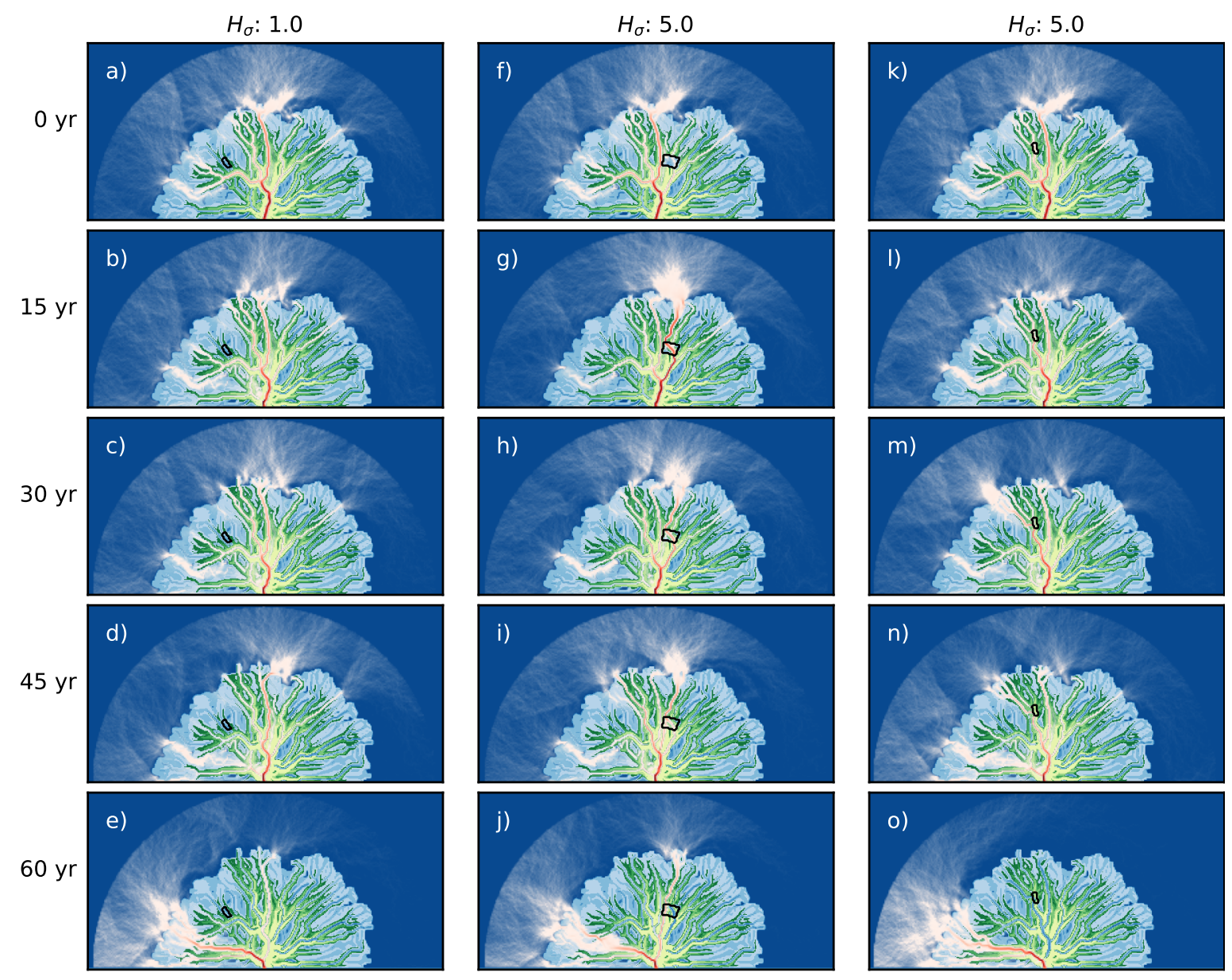

Figure S5. Planform evolution of the bed morphology and water discharge field following displacement for selected simulations from Experiment Set 2. In simulation depicted in first column (a-e), the fault area is relatively small and "not connected" to the inlet. The distributary network does not reorganize, and when a lobe-switching avulsion occurs later at 45-60 yr, the new channel pathway is not towards the subsided block. Simulation depicted in second column (f-j) exemplifies reorganization due to faulting-induced subsidence. Following displacement, the main distributary channel swiftly redirects to the subsided area, where it remains until the area has been filled with sediment and a lobe-switching avulsion relocates flow ( $\sim 45 \mathrm{yr}$ ). Simulation depicted in third column (k-o) shows reorganization, but not as clearly or substantially as second column. Difference between third and second column shows how reorganization depends on fault area (these simulations had the same displacement length and were "connected"). At the end of depicted time in third and first columns (60 yr), channel path selection during avulsion is towards the left of the frame, indicating that topography controls the pathway (Reitz et al., 2010). 
Table S1. Parameterization for Set 1 and Set 2 model simulations.

\begin{tabular}{lccl}
\hline \hline & Set 1 & Set 2 & units \\
\hline domain length \& width & 20,40 & 100,200 & $\mathrm{~km}$ \\
cell size & 0.15 & 0.75 & $\mathrm{~km}$ \\
inlet channel width & 800 & 2250 & $\mathrm{~m}$ \\
input water discharge & 4125 & 33750 & $\mathrm{~m}^{3} / \mathrm{s}$ \\
input sediment discharge & 4.1 & 67.5 & $\mathrm{~m}^{3} / \mathrm{s}$ \\
input sand percentage & 55 & 35 & $\%$ \\
inlet \& basin depth & 5 & 10 & $\mathrm{~m}$ \\
reference slope & 0.00015 & 0.00005 & - \\
sea level rise rate & 0 & 2 & $\mathrm{~mm} / \mathrm{yr}$ \\
intermittency factor & 0.019 & 0.019 & - \\
initial simulation duration & 600 & 2000 & $\mathrm{yr}$ \\
\hline
\end{tabular}

